\title{
WHISTLE-BLOWING FOR REWARD - FRIEND OR FOE? EXPLORING A POSSIBLE TAX WHISTLE-BLOWING PROGRAMME IN SOUTH AFRICA
}

\author{
Monray Marsellus Botha \\ BLC LLB LLM BCom (Hons) MCom LLD \\ Professor \& Head: Department of Mercantile \\ Law, University of Pretoria
}

Carika Fritz

LLB LLM LLD

Senior Lecturer, Department of Mercantile Law

University of Pretoria

\section{SUMMARY}

Tax evasion poses a serious threat to revenue collection. One way of obtaining information on taxpayers who fail to disclose certain sources of income for tax purposes is to use whistle-blowers. This article first considers whether the existing general regulatory framework pertaining to whistle-blowing in South Africa protects a whistle-blower from possible reprisals. Thereafter, whether an "evading" taxpayer's right of access to information and to administrative justice ${ }^{2}$ may play a role in exposing a whistle-blower's identity is reflected upon, as this may deter a person from blowing the whistle. The article further considers the contentious issue of whether a monetary or financial reward should be provided for tax whistle-blowers where previously undisclosed information regarding a taxpayer's non-compliance is brought to light, and whether this would be in line with the existing general regulatory framework governing whistle-blowing. Finally, it is recommended that regulators in South Africa implement a whistle-blowing programme designed to reveal information about substantial misconduct, not only in financial markets, but also in matters regarding tax evasion; this would include a reward for the whistle-blower in the event of successful enforcement action.

S 32 of the Constitution of the Republic of South Africa, 1996 (Constitution). $\mathrm{S} 33$ of the Constitution. 


\section{$1 \quad$ INTRODUCTION}

Tax enforcement is a "key margin of tax policy throughout the world" ${ }^{3}$ and, in recent years, governments across the world, including in South Africa, have taken ambitious steps to crack down on tax evasion, ${ }^{4}$ which poses a serious threat to revenue collection by government revenue services worldwide. One way of obtaining information on taxpayers who fail to disclose certain sources of income for tax purposes is to use whistle-blowers. Whistleblowing is an important tool in the prevention or detection of improper conduct, fraud and corruption. ${ }^{5}$ It not only serves to deter corruption and other fraudulent activities and misconduct, but can also play an important role in curbing tax evasion and in encouraging transparency, accountability and high standards of good governance. ${ }^{6}$ According to Transparency International, whistle-blowers play "an essential role in exposing corruption, fraud, mismanagement and other wrongdoing that threatens public health and safety, financial integrity, human rights, the environment, and the rule of law"; and, by "disclosing information about such misdeeds, whistle-blowers have helped save countless lives and billions of dollars in public funds, while preventing emerging scandals and disasters from worsening".

Many definitions of whistle-blowing exist. ${ }^{8}$ Transparency International proposes a broad, guiding definition of whistle-blowing as:

"the disclosure or reporting of wrongdoing, including but not limited to corruption; criminal offences; breaches of legal obligation; ${ }^{9}$ miscarriages of justice; specific dangers to public health, safety or the environment; abuse of authority; unauthorised use of public funds or property; gross waste or mismanagement; conflict of interest; ${ }^{10}$ and acts to cover up ... any of these."

3 Alstadsæter, Johannesen and Zucman "Tax Evasion and Tax Avoidance" (1 August 2018) http://gabriel-zucman.eu/files/AJZ2018b.pdf (accessed 2018-12-20) 1.

4 Kujinga A Comparative Analysis of the Efficacy of the General Anti-Avoidance Rule as a Measure Against Impermissible Income Tax Avoidance in South Africa (doctoral thesis, University of Pretoria) 201315 indicates that the distinction between tax evasion and tax avoidance lies in their legality. Tax evasion is the illegal failure to pay tax, while tax avoidance is not fundamentally illegal but consists in a taxpayer reducing the amount of tax payable by arranging his or her affairs accordingly.

5 See for e.g., Botha and Van Heerden "The Protected Disclosures Act 26 of 2000, the Companies Act 71 of 2008 and the Competition Act 89 of 1998 with regard to WhistleBlowing Protection: Is There a Link?" 20141 TSAR 337 337-358.

6 Botha and Van Heerden 2014 TSAR 338.

7 Transparency International Best Practice Guide for Whistleblowing Legislation (2018) 1.

Vinten "Whistleblowing towards Disaster Prevention and Management" 2000 Disaster Prevention and Management 18 18-21, where a restricted definition is put forward. Whistleblowing is defined as "the actions through which information is made known that an employee reasonably believes, provides proof of the transgression of any law or rule, mismanagement, corruption, abuse of authority, or that is a threat to public health and safety in the workplace" (Vinten 2000 Disaster Prevention and Management 19).

9 Including fraudulent financial disclosures made by government agencies/officials and publicly traded corporations (Transparency International Best Practice 7).

10 This could also include human rights violations if warranted or appropriate within a national context (Transparency International Best Practice 7).

11 Transparency International Best Practice 7. This definition also covers perceived or potential wrongdoing. 
In the context of the role that whistle-blowing plays in curbing various forms of financial misconduct (which includes tax evasion), it is important to note, as a starting point, that, while various conflicting rights and protections and potential pitfalls stem from whistle-blowing, whistle-blowing is "a powerful tool that the tax authorities of various countries use to curb tax evasion".

It is thus important to take note, not only of the information-gathering powers of the South African Revenue Service (SARS) but also, of taxpayer rights. Such rights are more than just a "philosophical abstraction"13 and it must be determined whether taxpayer rights can potentially be limited under a tax whistle-blower programme. ${ }^{14}$ In the latter context, due cognisance should be taken of Ferucci $v$ Commissioner of the South African Revenue Service. $^{15}$ In this case, the importance of SARS being able to gather information pertaining to a tax liability was highlighted, with the court stating:

"[a] situation which no doubt frequently arises is that information furnished by taxpayers is incomplete, inaccurate and sometimes misleading".

Gathering information to verify or establish taxpayer compliance becomes even more significant when bearing in mind that an increase in tax avoidance and tax evasion was one possible reason for the 2017/2018 fiscal year revenue shortfall.

SARS is empowered in terms of tax legislation and regulatory tools to gather information. According to Chapter 5 of the Tax Administration Act (TAA), ${ }^{18}$ SARS's information-gathering powers entail, inter alia, conducting an audit or criminal investigation, ${ }^{19}$ requesting relevant material from a taxpayer or a third party, ${ }^{20}$ and carrying out searches and seizures to gather information. $^{21}$ In addition to SARS gathering information itself, or requesting information, the TAA imposes a duty on a participant in certain types of arrangements to report these arrangements. ${ }^{22}$ Also, a taxpayer may make voluntary disclosures pertaining to a default in order to avoid criminal

12 Antinyan, Corazzini and Pavesi What Matters for Whistleblowing on Tax Evaders? (Survey and Experimental Evidence Working Paper Series, Department of Economics, University of Verona) 11.

13 Goulder Views From the Fourth Estate presented at The $3^{\text {rd }}$ International Conference on Taxpayer Rights: The Convergence of Good Governance and Legal Remedies Netherlands (May 2018) 2 (extended abstract).

14 Goulder Views From the Fourth Estate 3.

15 65 SATC 47.

6 Ferucci $v$ Commissioner of the South African Revenue Service supra 3.

7 National Treasury 2018 Budget Review (2018) 38.

28 of 2011.

$S 41$ of the TAA.

20 See $S 46$ of the TAA; and Vogelman "The Extensive Powers of SARS in Requesting 'Relevant Material'” (23 April 2014) Tax ENSight http://bit.ly/1xzsnYs (accessed 2018-1210) for a discussion of $s 46$ of the TAA.

21 Ss $59-63$ of the TAA.

22 Ss 34-38 of the TAA. 
prosecution, and may be granted some relief in relation to penalties arising from a default. ${ }^{23}$

The focus of this article is on SARS gathering information in a manner that is not provided for in the TAA - namely, by way of whistle-blowing. The role of whistle-blowers in the context of tax administration is important as whistleblowers can inform SARS of tax evasion and so aid its curtailment.

This article consists of three parts. In the first part, we consider the existing general regulatory framework pertaining to whistle-blowing in order to establish whether legislation would protect the whistle-blower against possible reprisals for making a disclosure. Secondly, we analyse the role that an "evading" taxpayer's right of access to information ${ }^{24}$ and to administrative justice ${ }^{25}$ may play in exposing a whistle-blower's identity. Lastly, we consider the contentious issue of whether a monetary or financial reward should be provided for tax whistle-blowers where previously undisclosed information regarding a taxpayer's non-compliance is brought to light, and whether this would be in line with the existing general regulatory framework for whistle-blowing. In this regard, the tax whistle-blower programmes of the United States of America (US) are considered as they provide financial incentives to a whistle-blower. It is anticipated that considering the US position will provide valuable lessons to the possibility of providing a financial incentive to tax whistle-blowers in South Africa.

\section{REGULATORY WHISTLE-BLOWING FRAMEWORK}

\section{Introduction}

Various pieces of legislation and regulatory policy documents contain provisions concerning corruption and whistle-blowing, and provide for the protection of whistle-blowers in South Africa. The most important of these is the Protected Disclosures Act (PDA). ${ }^{26}$ The PDA forms part of the whistleblowing framework, which includes other legislation such as the Constitution, the Labour Relations Act (LRA) $)^{27}$ and the Companies Act. ${ }^{28}$ The PDA is modelled on the first comprehensive law of its kind passed - namely, the United Kingdom's (UK) Public Interest Disclosure Act (PIDA) of 1998. ${ }^{29}$

\footnotetext{
Ss $225-233$ of the TAA.

$\mathrm{S} 32$ of the Constitution.

$\mathrm{S} 33$ of the Constitution.

26 of 2000 . Also referred to as the "principal Act" in light of the amendments.

66 of 1995.

71 of 2008.

See, in this regard, Botha and Van Heerden 2014 TSAR 338. The PIDA came into effect as Part IVA of the ERA of 1996. Major changes were effected to Part IVA of the ERA by the Enterprise and Regulatory Reform Act and minor amendments were made by the Small Business, Enterprise and Employment Act of 2015. In addition to being the model for the South African PDA, the PIDA has also been described as "an exemplary piece of legislation" in debates in countries such as the Netherlands, New Zealand and some Australian states (see, in this regard, Lewis "Nineteen Years of Whistleblowing Legislation in the UK: Is It Time for a More Comprehensive Approach?" 2017 59(6) International Journal of Law and Management 1126). Lewis points out that it is questionable whether the UK still provides for a suitable model, especially in light of international developments, in particular the Protected Disclosures Act of 2014 (Ireland) and the Public Interest Disclosure
} 


\section{The scope of the Protected Disclosures Act}

The PDA has been in operation since 2000. It gives due recognition to the rights contained in the Constitution, affirms the democratic values of human dignity, equality and freedom, places emphasis on accountability, transparency and corporate governance, and provides that criminal and other irregular conduct by state and private bodies is detrimental to good, effective, accountable and transparent governance in corporate bodies and organs of state..$^{30}$ The purpose of the PDA is to "create a culture which will facilitate the disclosure of information by employees and workers relating to criminal and other irregular conduct in the workplace in a responsible manner by providing comprehensive statutory guidelines for the disclosure of such information and protection against any reprisals as a result of such disclosures". ${ }^{31}$ The PDA also emphasises open and good corporate governance, while pointing to criminal and irregular conduct that can endanger the economic stability of the Republic and that has the potential to cause social harm. ${ }^{32}$

The PDA has recently been amended. ${ }^{33}$ The objectives of the PDA (before the amendments) read as follows:

"to make provision for procedures in terms of which employees in both the private and public sector may disclose information regarding unlawful or irregular conduct by their employers and/or other employees in the employ of their employers; to provide for the protection of those employees who make disclosures which are protected in terms of the Act; and to provide for matters connected therewith."

The PDA (after the amendments) now makes provision for

Act of 2013 (Australia), as well as the Council of Europe Protection of Whistle-Blowers, Recommendations CM/Rec (2014) 7 (Lewis 2017 International Journal of Law and Management 1126).

Botha and Van Heerden point out that the South African Competition Commission encourages "authorised whistle-blowing" by cartel members and has specifically adopted a corporate leniency policy for this purpose. In addition, the Prevention and Combating of Corrupt Activities Act 12 of 2004, for example, states that the purpose of the Act is to provide for the strengthening of measures to prevent and combat corruption and corrupt activities, to provide for the offence of corruption and offences relating to corrupt activities, and to place a duty on certain persons holding positions of authority to report certain corrupt transactions (see Botha and Van Heerden 2014 TSAR 339 in this regard).

30 The Preamble to the PDA.

31 The Preamble to the PDA (as amended). See also Grieve $v$ Denel (Pty) Ltd 20034 BLLR 366 (LC) 368 in this regard.

32 Every employer, employee and worker has a responsibility to disclose criminal and any other irregular conduct in the workplace, and every employer has a responsibility to take all necessary steps to ensure that employees and workers who disclose such information are protected from any reprisals as a result of such disclosure (Preamble to the PDA (as amended)).

33 The PDA has been amended by the Protected Disclosures Amendment Act 5 of 2017.

34 See, in this regard, Grieve $v$ Denel (Pty) Ltd supra and Engineering Council of SA $v$ City of Tshwane Metropolitan Municipality 2008 ILJ 899 (T). 
"procedures in terms of which employees and workers ${ }^{35}$ in both the private and the public sector may disclose information regarding unlawful or irregular conduct by their employers or other employees or workers in the employ of their employers; to provide for the protection of employees or workers who make a disclosure which is protected in terms of this Act; and to provide for matters connected therewith."

Prior to the amendments, the principal Act only granted protection to employees (in both the private and public sector) who blew the whistle. The amendments to the PDA are in line with other developments in labour legislation. Recently, the LRA was amended by the Labour Relations Amendment Act (LRAA) ${ }^{37}$ as the protection of vulnerable or a-typical employees $^{38}$ (such as those who work for temporary employment services ${ }^{39}$ and fixed-term and part-time employees) had become significant policy issues. ${ }^{40}$ Labour law usually distinguishes between employees, workers, the

35 Emphasis added. The definition of "worker" was inserted by the PDA Amendment Act and means-

"(a) any person who works or worked for another person or for the State; or

(b) any other person who in any manner assists or assisted in carrying on or conducting or conducted the business of an employer or client, as an independent contractor, consultant, agent; or

(c) any person who renders services to a client while being employed by a temporary employment service".

See also, for e.g., Smit and Botha "Is the Protected Disclosures Act 26 of 2000 Applicable to Members of Parliament?" 2011 TSAR 829, where they made calls for an amendment to the PDA. They are of the view that it is clear that, although the intended purpose of the PDA is to protect employees from occupational detriments, the need for wider protection existed and was addressed only to some extent by the then-current definition(s) and even those contained in the Companies Act.

36 Long title of the PDA as substituted by s 12 of the Protected Disclosures Amendment Act. Emphasis added.

376 of 2014. See, in this regard, ss 198A, 198B, 198C and 198D.

38 See, in this regard, Fourie "Non-Standard Workers: The South African Context, International Law and Regulation by the European Union" 2008 PER/PELJ 110 110-111; Smit and Fourie "Extending Protection to Atypical Workers, Including Workers in the Informal Economy, in Developing Countries" 2010 The International Journal of Comparative Labour Law and Industrial Relations 43.

39 A majority of the Constitutional Court recently, in Assign Services (Pty) Ltd Case CCT 194/17, and with reference to the Preamble of the LRAA, observed that "it aimed to provide greater protection for workers placed in temporary employment services" and that there appear to be two offshoots of this purpose: "the first is to protect marginal workers in temporary employment; and the second is for temporary employment services to be truly temporary" (par 65). The court further stated that the purpose of the section 198A amendment is clear - namely, to fill a gap in accountability between client companies and those who are placed with them (par 70). The majority concluded that, on an interpretation of ss $198(2)$ and $198 \mathrm{~A}(3)(b)$ of the LRA, the temporary employment service (TES) is the employer, and then subsequent to a time lapse, the client becomes the sole employer. The court further found that the language used in $\mathrm{s} 198 \mathrm{~A}(3)(b)$ of the LRA is plain and, when interpreted in the context, supports the sole-employer interpretation. The definition of "temporary employment service" was inserted by the Protected Disclosures Amendment Act and means:

"any person who, for reward, procures for or provides to a client other persons who-

(a) render services to, or perform work for, the client; and

(b) are remunerated by the temporary employment service." Own emphasis added.

40 These employees are referred to as "non-standard" employees. See, in this regard, Van Niekerk and Smit (eds) Law@work (2018) 59. 
self-employed and independent contractors. ${ }^{41}$ During 2002, both the LRA and the Basic Conditions of Employment Act (BCEA) ${ }^{42}$ were amended to introduce a rebuttable presumption of employment in respect of those claiming to be employees. ${ }^{43}$ The "Code of Good Practice: Who is an Employee?" was also introduced to assist parties in determining the existence of an employment relationship. Labour legislation such as the BCEA, the Employment Equity Act (EEA) ${ }^{44}$ and the Skills Development Act $(\text { SDA })^{45}$ all include a definition of "employee" similar to the one found in section 213 of the LRA, which defines an "employee" as:

"(a) any person, excluding an independent contractor, who works for another person or for the State and who receives, or is entitled to receive, any remuneration; and

(b) any other person who in any manner assists in carrying on or conducting the business of an employer ..."

The PDA's definition of "employee" has been amended and now differs from the latter one. It reads as follows: ${ }^{46}$

“(a) any person, excluding an independent contractor, who works or worked for another person or for the State, and who receives or received, or is entitled to receive, any remuneration; and

(b) any other person who in any manner assists or assisted in carrying on or conducting or conducted the business ${ }^{47}$ of an employer."

The definition of "employee" expressly excludes "independent contractors" from its ambit. The self-employed and independent contractors are often excluded because, traditionally, they could fend for themselves. ${ }^{48}$ Van

41 See s 213 of the LRA; Davies Perspectives on Labour Law (2009) 77.

4275 of 1997.

43 See s 200A of the LRA and s 83A of the BCEA. See, for e.g., Phaka $v$ Bracks 201536 ILJ 1541 where the court supported the arbitrator's consideration of section $200 \mathrm{~A}$ and stated: "Section 200A of the LRA seeks to assist vulnerable individuals in establishing employee status. Although section 200A leaves the definition of 'employee' unchanged, it creates a rebuttable presumption that a person who renders services to any other person is presumed, regardless of the form of the contract, to be an employee, if any one or more of a list of seven factors are present. Thus even if the contract of work purports to be that of independent contractor, if any one of the listed factors is present, that person is presumed to be an employee" (par 26). The enactment of $s$ 200A of the LRA and s 83A of the BCEA is in line with Employment Relationship Recommendation 198 of 2006 of the International Labour Organization (ILO). This recommendation recognises that protection should be accessible to particularly vulnerable workers and that challenges in determining the nature of the relationship can affect these workers and their communities and societies. This highlights the importance of extending protection to vulnerable workers as well as the impact in a wider sense on both immediate communities and societies. The recommendation calls for national policies to extend protection to workers in an employment relationship and states that these policies must provide guidance and indicia to determine the nature of the relationship and prevent disguised relationships.

4455 of 1998.

4597 of 1998.

46 Amendments underlined. See $\mathrm{s} 1$ of the Protected Disclosures Amendment Act.

47 S 1 of the Protected Disclosures Amendment Act inserted the definition of "business" into $\mathrm{s} 1$ of the PDA to mean "the whole or part of any business, trade, undertaking or service".

48 See also Smit and Botha 2011 TSAR 815-829 for a discussion of Charlton v Parliament of the Republic of South Africa 2007 ILJ 2263 (LC) and Parliament of the Republic of South 
Niekerk and Smit point out that "the nature of work has changed radically, and employment in post-apartheid South Africa has been characterised by 'casualisation' and 'externalisation'" and that this entails "a process whereby employers shape employment relations to informalise working arrangements and thus deprive employees of their basic statutory rights". ${ }^{49}$ They add that it was partly in response to these developments that the rebuttable presumption of employment was included in the LRA and the BCEA in $2002{ }^{50}$ This presumption, however, applies only to persons earning below a prescribed threshold amount. ${ }^{51}$ It is thus clear that the PDA has been amended in line with other developments and that its application extends to any person who works, or worked, for the State or another person, or who in any manner assists, or assisted, in carrying on or conducting the business of an employer or client as an independent contractor, consultant, agent or person rendering services to a client while being employed by a temporary employment service.

In addition to the provisions of the PDA on whistle-blowers, section 159 of the Companies $\mathrm{Act}^{52}$ also provides protection for whistle-blowing employees. ${ }^{53}$ However, it provides additional protection and does not replace the protection provided for by the PDA. ${ }^{54}$ The Companies Act further applies to a disclosure by an employee, as defined in the PDA, irrespective of whether the PDA would otherwise apply to that disclosure. ${ }^{55} \mathrm{~A}$ closer examination of section 159(3)(a) of the Companies Act provides clarity on the extension of protection to, for example, different role players in companies. The latter section provides that a disclosure will also be protected if made in good faith by a shareholder, director, company secretary, prescribed officer, registered trade union representative of the employees or any other representative of employees, a supplier of goods and services to the company, or even employees of a supplier, ${ }^{56}$ when the disclosure is made to the Companies and Intellectual Property Commission, the Companies Tribunal, the Takeover Regulation Panel, a regulatory

Africa $v$ Charlton 2010 ILJ 2353 (LAC) regarding whether members of Parliament are employees.

49 Van Niekerk and Smit Law@work 65.

50 The seven factors that trigger the presumption established by the LRA and the BCEA are: (a) the manner in which the person works is subject to the control or direction of another person; (b) the person's hours of work are subject to the control or direction of another person; (c) in the case of a person who works for an organisation, the person forms part of that organisation; (d) the person has worked for that person for an average of at least 40 hours per month over the last three months; (e) the person is economically dependent on the other person for whom he or she works or renders services; or (f) the person is provided with tools of the trade or work equipment by the other person; or $(\mathrm{g})$ the person only works for or renders service to one person.

51 Currently, the threshold stands at R205 433,30 per annum. Workers earning more will, of course, be able to use these factors as guidelines when establishing their status as an employee.

52 For a detailed discussion on s 159 of the Companies Act, see Botha and Van Heerden 2014 TSAR 343.

53 S 159(1)-(3) of the Companies Act.

54 S 159(1)(a) of the Companies Act.

$55 \mathrm{~S} 159(1)(b)$ of the Companies Act.

56 S 159(4) of the Companies Act. 
authority, ${ }^{57}$ an exchange, ${ }^{58}$ a legal adviser, a director, a prescribed officer, a company secretary, an auditor, a person performing the function of internal audit, and the board or committee of the company concerned. Any provision in a company's memorandum of incorporation or rules, or an agreement, is void to the extent that it is inconsistent with, or purports to limit, set aside or negate the effect of section 159 of the Companies Act.

\section{Types of disclosure}

In terms of section 1 of the PDA, "disclosure" means: ${ }^{60}$

"any disclosure of information ${ }^{61}$ regarding any conduct of an employer, or of an employee or of a worker of that employer, made by any employee or worker who has reason to believe that the information concerned shows or tends to show one or more of the following:

(a) that a criminal offence has been committed, is being committed or is likely to be committed;

(b) that a person has failed, is failing or is likely to fail to comply with any legal obligation to which that person is subject;

(c) that a miscarriage of justice has occurred, is occurring or is likely to occur;

(d) that the health or safety of an individual has been, is being or is likely to be endangered;

(e) that the environment has been, is being or is likely to be damaged;

(f) unfair discrimination as contemplated in Chapter II of the Employment Equity Act, 1998 (Act No. 55 of 1998), or the Promotion of Equality and Prevention of Unfair Discrimination Act, 2000 (Act No., 4 of 2000); or

(g) that any matter referred to in paragraphs (a) to ( $f$ ) has been, is being or is likely to be deliberately concealed".

A "protected disclosure" ${ }^{63}$ includes a disclosure made to a legal adviser, ${ }^{64}$ an employer, ${ }^{65}$ a member of Cabinet or of the executive council of a

57 A regulatory authority is defined by $\mathbf{s} 1$ of the Companies Act as "an entity established in terms of national or provincial legislation responsible for regulating an industry, or sector of an industry".

58 S 1 of the Companies Act provides that "exchange" when used as a noun has the meaning set out in $\mathrm{s} 1$ of the Securities Services Act 36 of 2004.

59 S 159(2) of the Companies Act.

60 Underlined sections indicate insertions in terms of the Protected Disclosures Amendment Act.

61 See for e.g., Grieve v Denel (Pty) Ltd supra where the court held as follows: "Prima facie they appear to be based on information which is documented and supported and although there may be adequate explanations and the reasons for providing the information may go beyond merely wishing to draw these matters to the attention of the management of the respondent, nonetheless in my assessment at a prima facie level the applicant has established that the disclosures were made bona fide."

62 In CWU v Mobile Telephone Networks (Pty) Ltd 2003 BLLR 741 (LC), the Labour Court confirmed that the definition of "disclosure" clearly contemplates that it is only the disclosure of information that either discloses or tends to disclose forms of criminal or other misconduct that is the subject of protection under the PDA (747a-b). See also Chowan $v$ Associated Motor Holdings (Pty) Ltd [2018] 2 All SA 720 (GJ) in this regard.

63 See, for e.g., Beaurain v Martin NO (1) 201435 ILJ 2442 (LC), where it was stated that a disclosure made on Facebook was not protected, as it was not made in a reasonable manner. 
province, ${ }^{66}$ or any other person or body.$^{67}$ Protected disclosures can also be made to the Public Protector or Auditor-General. ${ }^{68}$ This definition specifically excludes a disclosure if the employee or worker commits an offence by making the disclosure,$^{69}$ and also disclosures made by a legal adviser ${ }^{70}$ to whom the information concerned was disclosed in the course of obtaining legal advice in terms of section 5 of the PDA. It should be noted that, to earn

$64 \mathrm{~S} 5$ of the PDA.

65 S 6(1) of the PDA (as amended) provides in this regard as follows:

"(1) Any disclosure made in good faith-

(a) and substantially in accordance with any procedure [prescribed, or] authorised by the employee's or worker's employer for reporting or otherwise remedying the impropriety concerned and the employee or worker has been made aware of the procedure as required in terms of subsection (2)(a)(ii); or

(b) to the employer of the employee or worker, where there is no procedure as contemplated in paragraph (a), is a protected disclosure."

(2) (a) Every employer must-

(i) authorise appropriate internal procedures for receiving and dealing with information about improprieties; and

(ii) take reasonable steps to bring the internal procedures to the attention of every employee and worker.

(b) Any employee or worker who, in accordance with a procedure authorised by his or her employer, makes a disclosure to a person other than his or her employer, is deemed, for the purposes of this Act, to be making the disclosure to his or her employer."

$66 \mathrm{~S} 7$ of the PDA.

67 Ss 8 and 9 of the PDA.

68 S 8 of the PDA. The Protected Disclosures Amendment Act added the South African Human Rights Commission, the Commission for Gender Equality, the Commission for the Promotion and Protection of the Rights of Cultural, Religious and Linguistic Communities, and the Public Service Commission to persons and bodies to which or to whom an employee or worker can make a disclosure in good faith (s 8(aA), (a)(B), (a)(C) and (a)(D)).

69 S 9B was inserted by the Protected Disclosures Amendment Act and provides that, if an employee or worker intentionally discloses false information knowing that information to be false or ought reasonably to have known that the information is false, and with the intention to cause harm to the affected party and where the affected party has suffered harm as a result of such disclosure, such an employee or worker is guilty of an offence and is liable on conviction to a fine or to imprisonment for a period not exceeding two years, or to both a fine and such imprisonment (see s 9B(1)).

70 See, in this regard, Randles $v$ Chemical Specialities Ltd 2011 ILJ 1397 (LC), where the court noted specifically with regard to legal advisers that they appear in the PDA in two contexts:

"(i) The first is a disclosure made by an employee (the whistleblower) 'to' a legal adviser. It is clear from the definition of what constitutes a protected disclosure that a disclosure made 'to' a legal adviser (in terms of $s 5$ of the PDA) may be considered to be a 'protected' disclosure. (ii) The second is a disclosure 'by' a legal adviser of certain information. If regard is had to the definition of a 'protected disclosure' it appears that what is not protected in terms of the PDA is a disclosure 'by' a legal adviser of the information that was disclosed to him or her by an employee 'in the course of obtaining legal advice in accordance with section 5'. The person who will therefore not be able to claim the protection afforded by the PDA is firstly, the person whose occupation involves the giving of legal advice (s 5(a) of the PDA) and secondly, the person (in his capacity as legal adviser) who receives the disclosed information from someone (the whistleblower) who disclosed the information with the object of and in the course of obtaining legal advice (s 5(b) of the PDA). Once these two requirements have been met, the disclosures (by the legal adviser) will not be protected in terms of the PDA. What therefore appears to be specifically excluded from the protection of the PDA is that information disclosed to a legal adviser which normally falls within the parameters of what is referred to as 'legal privilege"' (par 22). 
protection, an employee or worker must therefore, first, make a disclosure that falls within the ambit of a disclosure as defined by the PDA; secondly, make a disclosure to a set category of persons; and, thirdly, make the disclosure in good faith and in accordance with a procedure authorised by his or her employer. ${ }^{71}$ It appears that, when an employee makes a disclosure to a person who has an interest in the matter, this will comply with the requirements set by the Act. Such a person would include a shareholder, as was confirmed in $\mathrm{H}$ and $\mathrm{MLtd}{ }^{72}$ where it was stated that although the information concerned was confidential it was disclosed to a shareholder who had an interest in the matter. The court in CWU $v$ Mobile Telephone Networks (Pty) Ltd, for example, held that, if an employee (or worker) makes a disclosure to an employer in terms of section 6 , a number of conditions must be met before the disclosure can be regarded as a protected disclosure. These conditions are:

(i) the person claiming the protection must be an employee (or worker);

(ii) the employee (or worker) must have reason to believe that information in his or her possession shows, or tends to show, the range of conduct that forms the basis of the definition of "disclosure";

(iii) the employee (or worker) must make the disclosure in good faith;

(iv) if there is a prescribed procedure, it must be adhered to;

(v) where a procedure is authorised by the employer for reporting or remedying any impropriety, then there must be substantial compliance with that procedure;

(vi) if there is no procedure that is either prescribed or authorised, then the disclosure must be made to the employer;

(vii) if any procedure authorised by the employer permits the making of a disclosure to a person who is not the employer, the employer is deemed to have made the disclosure; and

(viii) there ought to be some nexus between the disclosure and the detriment.

It should be noted that, unlike the PDA, the Companies Act also applies to persons other than employees, which includes stakeholders such as customers, suppliers, creditors and the government. Section 159(4) of the Companies Act provides a qualified privilege for a relevant disclosure made by a shareholder, director, company secretary, prescribed officer or employee of a company, a registered trade union that represents employees of the company or another representative of the employees of the company, a supplier of goods or services to a company, or an employee of such a

71 S 10 of the PDA empowers the Minister to make regulations for purposes of $s 8(1)$. This section is hereby amended by the substitution in subsection (4) for paragraphs $(a)$ and $(c)$ of the following paragraphs, respectively to read as follows:

“(a) The Minister must, after consultation with the Minister for the Public Service and Administration, issue practical guidelines which explain the provisions of this Act and all procedures which are available in terms of any law to employees or workers who wish to report or otherwise remedy an impropriety. ...

(c) All organs of state must give to every employee or worker a copy of the guidelines referred to in paragraph (a) or must take reasonable steps to bring the relevant notice to the attention of every employee or worker."

$72 \mathrm{H}$ and M Ltd 2005 ILJ 1737 (CCMA) 1791h. 
company. It protects these whistle-blowers from criminal, civil as well as administrative liability for making such a disclosure. ${ }^{73}$ Similarly, the newly inserted section 9A of the PDA provides for the exclusion of civil and criminal liability for an employee or worker as follows:

“(1) A court may find that an employee or worker who makes a protected disclosure of information-

(a) referred to in paragraph (a) of the definition of disclosure; or

(b) which shows or tends to show that a substantial contravention of, or failure to comply with the law has occurred, is occurring or is likely to occur, shall not be liable to any civil, criminal or disciplinary proceedings by reason of having made the disclosure if such disclosure is prohibited by any other law, oath, contract, practice or agreement requiring him or her to maintain confidentiality or otherwise restricting the disclosure of the information with respect to a matter.

(2) Exclusion of liability as contemplated in subsection (1) does not extend to the civil or criminal liability of the employee or worker for his or her participation in the disclosed impropriety."

It should further be noted that the PDA draws a distinction between internal $^{75}$ and external disclosures. It is clear that, if an employee or worker (in terms of the PDA) or any other person (in terms of the Companies Act) makes a disclosure internally, and any of the parties to whom the disclosure is made fails to take any action regarding the disclosure, such a person can then repeat the disclosure to an external party. It is apparent that protection for an external disclosure is dependent on the internal disclosure, because it must be established whether an employee blew the whistle internally before doing so externally. ${ }^{76}$ In this regard, due cognisance should be taken of section 9 of the PDA. Section 9 affords protection to whistle-blowers who make external disclosures under the general disclosure provision of the PDA. For example, in Engineering Council of SA $v$ City of Tshwane Metropolitan Municipality, ${ }^{77}$ the court found that the second applicant had made a general protected disclosure and that he reasonably believed that the information disclosed as well as the allegation made by him were substantially true. The court noted that he had previously made a disclosure

73 The Competition Act 89 of 1998, for example, introduced a "corporate leniency policy" in terms of which the Competition Commission also encourages "authorised whistle-blowing" by cartel members. See, in this, regard Van Heerden and Botha "Challenges to the South African Corporate Leniency Policy and Cartel Enforcement” 20152 TSAR 308 308-333.

74 S 1 of the PDA defines an impropriety as:

"any conduct which falls within any of the categories referred to in paragraphs (a) to $(g)$ of the definition of 'disclosure', irrespective of whether or not

(a) the impropriety occurs in the Republic of South Africa or elsewhere;

(b) the law applying to the impropriety is that of the Republic of South Africa or of another country".

75 S 6(2)(a) of the PDA (as amended) provides that every employer must (i) authorise appropriate internal procedures for receiving and dealing with information about improprieties; and (ii) take reasonable steps to bring the internal procedures to the attention of every employee and worker. Any employee or worker who, in accordance with a procedure authorised by his or her employer, makes a disclosure to a person other than his or her employer, is deemed, for the purposes of the PDA, to be making the disclosure to his or her employer.

76 See, in this regard, Botha and Van Heerden 2014 TSAR 346.

77 Engineering Council of SA v City of Tshwane Metropolitan Municipality supra. 
of substantially the same information to his employer, but that no action was taken within a reasonable time after the disclosure had been made. ${ }^{78}$ The court added that the impropriety was of an "exceptionally serious nature" and that, when the reasonableness of the disclosure was tested against the provisions of section $9(3)$ of the PDA, the disclosure was manifestly in the public interest. $^{79}$

The protection granted in terms of section 9 of the PDA under the general disclosure provision is subject to the employee (or worker) first complying with certain conditions, as the court in Tshishonga $v$ Minister of Justice and Constitutional Development ${ }^{80}$ pointed out. These are:

(i) the disclosure must be made in good faith; ${ }^{81}$

(ii) the employee (or worker) must have a reasonable belief that the information is substantially true; and

(iii) the disclosure should not be for personal gain.

Botha and Van Heerden note:

"[i]n the context of determining whether an external disclosure is protected the test is more stringent."

The reasonableness ${ }^{83}$ of the belief must relate to the information being substantially true. ${ }^{84}$

78 Engineering Council of SA v City of Tshwane Metropolitan Municipality supra 935b-e.

79 Engineering Council of SA v City of Tshwane Metropolitan Municipality supra 935e.

8020074 BLLR 327 (LC).

81 See, for e.g., SA Municipal Workers Union National Fund v Arbuthnot 201435 ILJ 2434

(LAC) par 23 where the court stated the following: "Good faith, in my view, entails in part that there should be no ulterior motive, revenge or malice in making the disclosure." In Tshishonga $v$ Minister of Justice and Constitutional Development supra, the court emphasised that:

"[b]y setting good faith as a specific requirement, the legislature must have intended that it should include something more than reasonable belief and the absence of personal gain. An employee may reasonably believe in the truth of the disclosures and may gain nothing from making them, but his good faith or motive would be questionable if the information does not disclose an impropriety or if the disclosure is not aimed at remedying a wrong. A whistle-blower, who is overwhelmed by an ulterior motive, that is, a motive other than to prevent or stop wrongdoing, may not claim the protection under the PDA. The requirement of good faith therefore invokes a proportionality test to determine the dominant motive. Good faith is required to test the quality of the information. A malicious motive cannot disqualify the information if the information is substantial. A malicious motive could affect the remedy awarded to the whistle-blower" (362g-364f).

See, also, L-A J v Afrox Oxygen Ltd [2015] 12 BLLR 1213 (LC) in this regard. See also in this regard Street $v$ Unemployed Workers' Centre [2004] 4 All ER 839 par 41, where the court considered the meaning of the requirement "in good faith" for a disclosure to qualify as a protected disclosure. The court attached the following meaning to the "in good faith" requirement:

"Shorn of context, the words 'in good faith' have a core meaning of honesty. Introduce context, and it calls for further elaboration. Thus in the context of a claim or representation, the sole issue as to honesty may just turn on its truth. But even where the content of the statement is true or reasonably believed by its maker to be true, an issue of honesty may still creep in according to whether it is made with sincerity of intention for which the Act provides protection or for an ulterior and, say, malicious purpose." (par 41).

822014 TSAR 346. 
Against this backdrop, one should take note of, for example, the PIDA of 1998 (UK), which provides for the protection of workers in non-profit, private and government sectors and covers a wide range of whistle-blower categories such as employees, contractors, trainees, and even UK workers

83 See, in this regard, SA Municipal Workers Union National Fund $v$ Arbuthnot supra, where the court stated that the enquiry is not about the reasonableness of the information, but about the reasonableness of the belief that the information is true; the "requirement of 'reasonable belief' does not entail demonstrating the correctness of the information, because a belief can still be reasonable even if the information turns out to be inaccurate" (par 15). See, also, Radebe v Premier Free State Province 2012 (5) SA 100 (LAC) par 36, where it was held:

"The requirement of 'reason to believe' cannot be equated to personal knowledge of the information disclosed. That would set so high a standard as to frustrate the operation of the PDA. Disclosure of hearsay and opinion would, depending on its reliability, be reasonable. A mistaken belief or one that is factually inaccurate can nevertheless be reasonable, unless the information is so inaccurate that no one can have any interest in its disclosure."

Delport observes in this regard as follows:

"The fact that the whistle-blower is required to show that he/she 'reasonably believed' the disclosed information to be of a particular nature, indicates the application of an objective test - whether the notional reasonable person would have held the same belief. A mere subjective belief by the whistle-blower that the disclosed information shows a breach of the law as indicated in s $159(3)(b)(i)-(v)$ will not bring the whistle-blower within the scope of the protection offered by this section. The reasonable belief must furthermore be held 'at the time of the disclosure' in order for the whistle-blower to be afforded the protection under this section" (Delport "Remedies and Enforcement" in Henochsberg on the Companies Act 71 of 2008 and Commentary (2018) 560(18)).

84 See, for e.g., Radebe v Mashoff Premier of Free State Province 20096 BLLR 564 (LC), where the court was of the view that "clearly speculations and opinions do not amount to facts upon which a reason to believe can be based" and that the word "reason" "means basis, in a form of facts and not baseless speculations or opinion" (par 50), and found that the disclosure did not meet the requirements of $s 9$ of the PDA because the information was not substantially true (par 89). It should also be noted that s 159(3)(b) of the Companies Act provides that the person (including an employee or worker) making the disclosure must reasonably have believed at the time of the disclosure that the information showed or tended to show that a company or external company, or a director or prescribed officer of a company acting in that capacity, had contravened the Companies Act or a law mentioned in Schedule 4 of the Companies Act. This provision is also applicable when a company or external company, or a director or prescribed officer of a company acting in that capacity, has failed or is failing to comply with any statutory obligation to which the company is subject, or has engaged in conduct that has endangered or is likely to endanger the health or safety of any individual, or damage the environment, or has unfairly discriminated, or condoned unfair discrimination, against any person, as contemplated in $s 9$ of the Constitution and the Promotion of Equality and Prevention of Unfair Discrimination Act 4 of 2000 , or has contravened any other legislation in a manner that could expose the company to an actual or contingent risk of liability, or is inherently prejudicial to the interests of the company. It is clear from the above that, in the context of public institutions, the PDA specifically emphasises public interest, whereas the Companies Act places an emphasis on the best interests of the company. This is evident from the provisions of the respective Acts. What is also evident is that disclosures can be made in terms of both Acts to a legal adviser, whereas the other categories of person clearly differ. However, it appears that a disclosure by a legal adviser of the information that was disclosed to him or her by an employee in the course of obtaining legal advice in accordance with s 5 of the PDA is not protected in terms of the PDA. See, in this, regard Botha and Van Heerden 2014 TSAR 347. See, also, Theron v Minister of Correctional Services 2008 BLLR 458 (LC), where the court had to investigate whether the disclosure was a protected disclosure, because it was not made to the employer, a member of Cabinet or executive council or a body envisaged by $s$ of the PDA. The court was left with the task of assessing if it was protected by $s$ of the PDA and was satisfied that the conditions in $s 9$ had been met and that the applicant suffered an occupational detriment by being transferred against his will (466a-467h)). 
based abroad. The PIDA inserted Part IVA of the Employment Rights Act of 1996 (ERA), which enables workers to make a "protected disclosure" defined by section $43 \mathrm{~A}$ of the ERA as "a qualifying disclosure". A "qualifying disclosure" is "any disclosure of information which, in the reasonable belief of the worker making the disclosure, is made in the public interest" and tends to show, for example, that a criminal offence has been committed, is being committed or is likely to be committed. It also includes failure to comply with a legal obligation and a miscarriage of justice. The PIDA, similarly to the PDA, also provides for internal as well as external disclosures. In April 2013, the "public-interest" test was included in order to govern instances where workers reasonably believe that the disclosure is being made in the public interest. ${ }^{85}$ These workers are protected against reprisals for making a qualified disclosure. Government removed the good-faith requirement, which is therefore no longer applicable to disclosures made on or after 25 June $2013{ }^{86}$ Previously, where a disclosure was made with an ulterior motive, it

85 In Chesterton Global Ltd v Nurmohamed (Public Concern at Work intervening) [2018] 1 All ER 947, the court held that, in addressing s 43B of the 1996 Act and the words added by the 2013 Act, the tribunal thus had to ask:

"(a) whether the worker believed, at the time that he was making it, that the disclosure was in the public interest and

(b) whether, if so, that belief was reasonable[,]

[and] hardly moving much further from the obvious, element (b) in that exercise requires the tribunal to recognise, as in the case of any other reasonableness review, that there may be more than one reasonable view as to whether a particular disclosure was in the public interest; and that is perhaps particularly so given that that question is of its nature so broadtextured" (par 27-28).

The necessary belief was simply that the disclosure was in the public interest as the particular reasons for the worker's belief were not of the essence, meaning that a disclosure:

"did not cease to qualify simply because the worker sought to justify it after the event by reference to specific matters which the tribunal finds were not in his head at the time he made it. While the worker had to have a genuine (and reasonable) belief that the disclosure was in the public interest, that did not have to be his or her predominant motive in making it. The question whether a disclosure was in the public interest depended on the character of the interest served by it rather than simply on the numbers of people serving that interest. That was the ordinary sense of the phrase "in the public interest"' (par 29).

The court added that, while the worker must have a genuine (and reasonable) belief that the disclosure was in the public interest:

"that does not have to be his or her predominant motive in making it: otherwise ..., the new ss $49(6 \mathrm{~A})$ and $103(6 \mathrm{~A})$ would have no role. I am inclined to think that the belief does not in fact have to form any part of the worker's motivation - the phrase 'in the belief' is not the same as 'motivated by the belief'; but it is hard to see that the point will arise in practice since where a worker believes that a disclosure is in the public interest it would be odd if that did not form at least some part of their motivation in making it" (par 30).

86 See, for e.g., Chesterton Global Ltd v Nurmohamed supra, where the court confirmed that the requirement of good faith was removed by s 18 of the 2013 Act, and with effect from 25 June 2013. The court added that a new subsection (6A) was introduced into both s 49 and s 123 of the 1996 Act, giving the Employment Tribunal the power to reduce any compensatory award for unlawful detriment or unfair dismissal by up to $25 \%$ if it found that the disclosure in question was not made in good faith. In other words, "the question of good faith is no longer relevant to liability in a whistle-blowing case but it remains relevant to remedy" (par 16). 
would thus be made in bad faith. ${ }^{87}$ It should be noted that several international instruments require that disclosures be made "in good faith" and on "reasonable grounds". 88 The good-faith requirement has generated a major policy debate: some link this requirement to "the information disclosed, meaning that the requirement is fulfilled if the person making a disclosure believes that the information they are providing is true", while others link the good-faith requirement to "the personal motivation of the whistle-blower, considering protection should be limited to 'honest' workers, and/or those who are motivated to speak up because they want the wrongdoing to be investigated (not because they are pursuing a personal agenda or vendetta)". ${ }^{89}$ It should be noted that these are understandable concerns, "but a good faith requirement can have the negative effect of shifting the focus from assessing the merits of the information provided to investigating the whistle-blower's motives, exposing him or her to personal attacks", which can "pose a serious deterrent to potential whistle-blowers".

\section{Detriments and remedies}

Section 3 of the PDA (as amended) provides that no employee or worker may be subjected to any occupational detriment by his or her employer on account of having made a protected disclosure. ${ }^{91}$ Moreover, the LRA provides for the protection of employees or workers who make a protected disclosure in terms of the PDA against suffering an "occupational detriment"; an occupational detriment in a whistle-blowing context will amount to an unfair labour practice or automatically unfair dismissal..$^{92}$ Sections 186(2) and $187(1)$ of the LRA provide that an employee who makes a protected disclosure in terms of the PDA is protected against any occupational detriment. ${ }^{93}$ An occupational detriment in relation to the work environment of an employee or worker includes, inter alia, an employee being subjected to

87 In this regard, see $S 43 A-43 F$ of the ERA as well as Transparency International "Whistleblowing in Europe: Legal Protections for Whistleblowers in the EU" (2013) www.transparency.org (accessed 2019-02-07) 83.

88 For e.g., the OECD Anti-Bribery Convention, the United Nations Convention against Corruption (UNCAC) and the Civil Law Convention of the Council of Europe on Corruption. See also Transparency International Best Practice 15. Transparency International Best Practice 15.

90 Ibid.

91 See, for e.g., CWU v Mobile Telephone Networks supra 746g, where the court stated that it is clear that there must be "some demonstrable nexus between making of the disclosure and the occupational detriment threatened or applied by the employer" for the protection of the PDA to apply. See, also, s 159(6) of the Companies Act which provides as follows:

"Any conduct or threat contemplated in subsection (5) is presumed to have occurred as a result of a possible or actual disclosure that a person is entitled to make, or has made, unless the person who engaged in the conduct or made the threat can show satisfactory evidence in support of another reason for engaging in the conduct or making the threat."

See, also, Theron $v$ Minister of Correctional Services supra 466a-467h and Rand Water Staff Association obo Snyman/Rand Water 20016 BALR 543 (P) 547c in this regard.

92 See $\mathrm{s} 186$ and 187 of the LRA.

93 See, also, s 159(4) of the Companies Act, which provides that a shareholder, director, company secretary, prescribed officer or employee of a company, a registered trade union that represents employees of the company or another representative of the employees of that company, a supplier of goods or services to a company, or an employee of such supplier who blows the whistle has a "qualified privilege" in respect of the disclosure. 
any disciplinary action, dismissal, suspension, demotion, harassment, intimidation, or transfer against his or her will. ${ }^{94}$ Section $186(2)(d)$ of the LRA specifically makes provision for the protection of an employee against the wrongful suffering of an occupational detriment, short of dismissal, for making a protected disclosure. This provision implies that the provision in section 23(1) of the Constitution that everyone has the right to fair labour practices is guaranteed to an employee (or worker) who makes a protected disclosure. Section $187(1)(h)$ of the LRA provides that the dismissal of an employee is automatically unfair $^{95}$ if the reason for his or her dismissal amounts to a contravention by the employer of the PDA because an employee has made a protected disclosure in terms of the PDA. In State Information Technology Agency (Pty) Ltd $v$ Sekgobela, ${ }^{96}$ the Labour Appeal Court stated with reference to Maimela $v$ UNISA ${ }^{97}$ that, where it is alleged

94 See s 1 of the PDA (as amended). Other occupational detriments include being refused a promotion or a transfer, being subjected to a term or condition of employment or retirement that is altered or kept altered to the whistle-blower's disadvantage, being refused a reference, or being provided with an adverse reference by the employer, as well as being denied appointment to any employment, profession or office. An occupational detriment also includes any civil claim for the alleged breach of a duty of confidentiality or a confidentiality agreement arising out of a disclosure of any criminal offence as well as information that shows or tends to show that "a substantial contravention of, or failure to comply with, the law has occurred, is occurring or is likely to occur" (s 1 of the PDA (as amended)). It also includes threats by means of any of the former actions as well as being adversely affected in respect of the employee or worker's employment, profession or office, including employment opportunities and work security and the retention or acquisition of contracts to perform work or render services.

95 See, in this regard, Pedzinski v Andisa Securities (Pty) Ltd (formerly SCMB Securities (Pty) Ltd) 2006 ILJ 362 (LC) 378a. See, also, John v Afrox Oxygen Ltd 201829 ILC 1278 (LC). The central question is whether, having made a protected disclosure, the whistle-blower was dismissed on account thereof (such as to render her or his dismissal automatically unfair) or on account of some other reason such as operational requirements. In such an instance, the issue is of one of causation (see, in this regard, Magagane $v$ MTN SA (Pty) Ltd [2017] JOL 36884 (LC) par 74). See also, for e.g., SA Chemical Workers Union v Afrox Ltd 199920 ILJ 1718 (LAC), where the Labour Appeal Court held as follows:

"This issue (the reason for the dismissal) is essentially one of causation and I can see no reason why the usual twofold approach to causation, applied in other fields of law, should not also be utilized here [authorities omitted]. The first step is to determine factua causation: was participation or support, or intended participation or support, of the protected strike a sine qua non (or prerequisite) for the dismissal? Put another way, would the dismissal have occurred if there was no participation or support of the strike? If the answer is yes, then the dismissal was not automatically unfair. If the answer is no, that does not immediately render the dismissal automatically unfair; the next issue is one of legal causation, namely whether such participation or conduct was the 'main', or 'dominant', or 'proximate', or 'most likely' cause of the dismissal. There are no hard and fast rules to determine the question of legal causation [authority omitted]. I would respectfully venture to suggest that the most practical way of approaching the issue would be to determine what the most probable inference is that may be drawn from the established facts as a cause of the dismissal, in much the same way as the most probable or plausible inference is drawn from circumstantial evidence in civil cases. It is important to remember that at this stage the fairness of the dismissal is not yet an issue. ... Only if this test of legal causation also shows that the most probable cause for the dismissal was only participation or support of the protected strike, can it be said that the dismissal was automatically unfair in terms of s 187(1)(a)" (par 32).

96201233 ILJ 2374 (LAC) par 15.

$97 \quad 201031$ ILJ 121 (LC) par 32. 
that the dismissal is automatically unfair, the situation is not much different save that:

"the evidentiary burden to produce evidence that is sufficient to raise a credible possibility that an automatically unfair dismissal has taken place rests on the applicant [employee]. If the applicant succeeds in discharging his evidentiary burden then the burden to show that the reason for the dismissal did not fall within the circumstances envisaged by $\mathrm{s} 187(1)$ of the LRA rests with [the employer]."

Whistle-blowers are also provided with other remedies and protections. Section 188A(11) of the LRA now provides that, if an employee alleges in good faith that the holding of an inquiry contravenes the PDA, that employee or the employer may require that an enquiry be conducted in terms of section 188A into allegations by the employer into the conduct or capacity of the employee. ${ }^{99}$ The newly inserted section 3B provides that any person or body to whom or to which a protected disclosure has been made ${ }^{100}$ must, subject to subsection (3), ${ }^{101}$ and as soon as reasonably possible, but in any event within 21 days after the protected disclosure has been made, (i) decide whether to investigate the matter, or refer the disclosure to another body or person if the disclosure could be investigated or dealt with more

98 The court in State Information Technology Agency (Pty) Ltd v Sekgobela supra also stated that it is "evident therefore that a mere allegation that there is a dismissal is not sufficient but the employee must produce evidence that is sufficient to raise a credible possibility that there was an automatically unfair dismissal". See, also, s 192 of the LRA; Nxumalo v Minister of Correctional Services 201637 ILJ 177 (LC) regarding the onus of proof. In Tshishonga v Minister of Justice and Constitutional Development supra 365, the court emphasised that unfair labour practices and unfair dismissals are occupational detriments and that the employer ultimately bears the burden of proving that it did not commit an unfair labour practice or dismiss the employee unfairly. See, also, Randles $v$ Chemical Specialities Ltd supra par 33, where the court was of the view "that there are persuasive policy considerations in not placing an unnecessary onus on the person seeking the protection of the PDA. By doing so it may have the effect of preventing or deterring a legitimate whistleblower from claiming the protection afforded to him or her by the PDA".

99 See, also, Letsoalo v Minister of Police; TRC Sesing v Minister of Police [2016] 8 BLLR 793 (LC) par 26, where the court stated that the effect of the provision in $S 188 \mathrm{~A}(11)$ is that either the employer or the employee may insist on a disciplinary inquiry concerning the employee's conduct or capacity being conducted by a CCMA (Commission for Conciliation, Mediation and Arbitration) arbitrator or a bargaining council. This provision was introduced into the LRAA in 2015 to prevent spiralling collateral litigation in cases in which a protected disclosure is alleged.

100 In terms of Ss 6-8 of the PDA.

$101 \mathrm{~S} 3 \mathrm{~B}(3)$ of the PDA provides as follows:

"The person or body, referred to in subsection (1) or (2), who is unable to decide within 21 days whether a matter should be investigated or not, must-

(a) in writing inform the employee or worker-

(i) that he, she or it is unable to take the decision within 21 days; and

(ii) on a regular basis, at intervals of not more than two months at a time, that the decision is still pending; and

(b) as soon as reasonably possible, but in any event within six months after the protected disclosure has been made or after the referral has been made, as the case may be, in writing inform the employee or worker of the decision-

(i) to investigate the matter, and where possible, the time-frame within which the investigation will be completed; or

(ii) not to investigate the matter and the reasons for such decision." 
appropriately by that other person or body; ${ }^{102}$ and (ii) in writing acknowledge receipt of the disclosure by informing the employee or worker of the decision made. The latter will include information on the decision made as to whether (a) to investigate the matter, and, where possible, on the time frame within which the investigation will be completed; or (b) not to investigate the matter and the reasons for such decision; or (c) to refer the disclosure to another person or body. The person or body must, at the conclusion of an investigation, inform the employee or worker of the outcome thereof. ${ }^{103}$

Section 4(1) of the PDA (as amended) provides that any employee who has been, is or may be subjected to an occupational detriment in breach of section 3 of the PDA, or anyone acting on behalf of an employee who is not able to act in his or her own name, may approach any court that has jurisdiction (including the Labour Court) for appropriate relief, as well as pursue any other process allowed or prescribed by law. In addition, section $4(1 \mathrm{~A})$ was inserted and provides that any worker who has been, is or may be subjected to an occupational detriment in breach of section 3 of the PDA, or anyone acting on behalf of a worker who is not able to act in his or her own name, may approach any court having jurisdiction for appropriate relief.

Section $3 \mathrm{~A}$ as inserted in the PDA also provides for joint and several liability and states that, where "an employer, under the express or implied authority or with the knowledge of a client, subjects an employee or a worker to an occupational detriment, both the employer and the client are jointly and severally liable".

To reach the remedy stage, the applicant must successfully prove that he or she made a protected disclosure and was subjected to an "occupational detriment". ${ }^{104}$ A court (including the Labour Court) or tribunal, if it is satisfied that an employee or worker has been subjected to, or will be subjected to, an occupational detriment on account of a protected disclosure, may make an appropriate order that is just and equitable in the circumstances. ${ }^{105}$ Such an order may include (a) payment of compensation by the employer or client, as the case may be, to that employee or worker; (b) payment by the employer or client, as the case may be, of actual damages suffered by the employee or worker; ${ }^{106}$ or (c) an order directing the employer or client, as the

$102 \mathrm{~S} 3(\mathrm{~B})(2)$ of the PDA provides that the person or body to whom a disclosure is referred as contemplated in this context:

"must, subject to subsection (3), as soon as reasonably possible, but in any event within 21 days after such referral-

(a) decide whether to investigate the matter or not; and

(b) in writing inform the employee or worker of the decision-

(i) to investigate the matter, and where possible, the time-frame within which the investigation will be completed; or

(ii) not to investigate the matter and the reasons for such decision".

${ }_{103} \mathrm{~S} 3 \mathrm{~B}(4)$ of the PDA.

104 See, in this regard, Tshishonga $v$ Minister of Justice and Constitutional Development supra 375 as well as Radebe $v$ Mashoff Premier of Free State Province supra par 82.

$105 \mathrm{~S} 4(1 \mathrm{~A})$ of the PDA.

$106 \mathrm{~S}$ 159(5) of the Companies Act provides that such a person is entitled to compensation from another person for any damages suffered if the first person is entitled to make, or has 
case may be, to take steps to remedy the occupational detriment. ${ }^{107}$ Section (4)(2) of the PDA was inserted and now provides that any dismissal in breach of section 3 of the PDA is deemed to be an automatically unfair dismissal as contemplated in section 187 of the LRA, and that the dispute about such a dismissal may follow the procedure set out in Chapter VIII of the LRA, or any other process, to recover damages in a competent court. It further provides that any other occupational detriment in breach of section 3 of the PDA is deemed to be an unfair labour practice as contemplated in section 186(2) of the LRA, and that the dispute about such an unfair labour practice must follow the procedure set out in section 191 of the LRA, provided that, if the matter fails to be resolved through conciliation, it may be referred to the Labour Court for adjudication. It should be noted that, in the case of an unfair labour practice, a maximum of 12 months' compensation could be granted, whereas with automatically unfair dismissals a maximum of 24 months' compensation could be granted. ${ }^{108}$ The compensation of 24

made, a disclosure contemplated in this section and, because of that possible or actual disclosure, the second person:

"(a) engages in conduct with the intent to cause detriment to the first person, and the conduct causes such detriment; or

(b) directly or indirectly makes an express or implied threat, whether conditional or unconditional, to cause any detriment to the first person or to another person, and-

(i) intends the first person to fear that the threat will be carried out; or

(ii) reckless as to causing the first person to fear that the threat will be carried out, irrespective of whether the first person actually feared that the threat would be carried out".

It should be noted that "detriment" in this context, unlike "occupational detriment" in the PDA, is not defined by the Companies Act (see Botha and Van Heerden 2014 TSAR 351 in this regard).

107 S 4(1A) of the PDA. See, for e.g., Tshishonga $v$ Minister of Justice and Constitutional Development supra 375, where the court held that the applicant was subjected to occupational detriment regardless of being paid during his suspension and being assured of remuneration until he reached the retirement age of 65 . As a result of the settlement, he had been denied the dignity of employment.

108 See ss 193 and 194 of the LRA in this regard. The court in Tshishonga $v$ Minister of Justice and Constitutional Development supra stated that an employee who suffers an "occupational detriment" is in a position similar to one who is victimised or discriminated against and that compensation awards for discrimination are therefore guidelines for these claims. It should be noted that the purpose of compensation is to provide redress for patrimonial and non-patrimonial losses (see Botha and Van Heerden 2014 TSAR 349 as well as Botha and Siegert "Minister for Justice and Constitutional Development $v$ Tshishonga 20099 BLLR 862 (LAC)" 2011 De Jure 479 479-489 for a discussion of just and equitable compensation for non-patrimonial loss). Botha and Van Heerden point out that "[i]t appears that such an employee's protection would in most instances where he or she blew the whistle be limited to remuneration of 24 months (should the employer's conduct be held to constitute automatically unfair dismissal), if one argues on the basis that sections 186(2) and 187 of the Labour Relations Act serve as a lex specialis to section 3 of the Protected Disclosures Act". The courts have, however, not hesitated in the past to grant, in addition to patrimonial loss, an order for the payment of non-patrimonial loss to the employee whistle-blower who has suffered an "occupational detriment" (Botha and Van Heerden 2014 TSAR 357). See, in this regard, Minister for Justice and Constitutional Development $v$ Tshishonga supra where the Labour Appeal Court was faced with the question of what is just and equitable in circumstances where the compensation is for nonpatrimonial loss. The court stated that assistance can be gained from the actio injuriarum which is granted for a solatium. It stated that, in cases of solatium, "the award is, subject to one of exception of a non-patrimonial nature, and is in satisfaction of the person who has suffered an attack on their dignity and reputation or an onslaught on their humanity" (par 18). The court added that the exception was for the amount relating to the costs of 
months is different from that in cases where the employer did not prove that the reason for dismissal was a fair reason related to the employee's conduct, capacity or the employer's operational requirements or because the employer did not follow a fair procedure, or both. ${ }^{109}$ In these instances, the compensation must be "just and equitable", ${ }^{110}$ but not more than the equivalent of 12 months' remuneration. ${ }^{111}$ When determining the amount of compensation that is reasonable, fair and equitable, particular criteria must be taken into account. ${ }^{112}$ It will also be within the court's power to grant an order of reinstatement if the employee was dismissed. In terms of section 193(2) of the LRA, an order of reinstatement ${ }^{113}$ would also be available to

R177 000 which were incurred by the respondent when he had to defend himself, and which were patrimonial in nature. The court also stated that the respondent must be compensated for the R177 000 because he had to defend himself "against the wholly unwarranted onslaught launched against him" (par 19). The court held that the following factors could be taken into account when quantifying compensation: (i) the embarrassment and humiliation the respondent had suffered by being summarily removed from his post without any reason given and thereafter being subjected to a suspension and subsequent disciplinary hearing; (ii) his being called a "dunderhead" by the Minister of Justice on national television and being rapped over the knuckles for poor work performance (which was not true); (iii) gross humiliation by being moved to a position which was non-existent at the time and being thereafter without any work or without work instructions for long periods; (iv) the undisputed evidence of the respondent that, because of all the humiliation, victimisation and harassment by the appellant, he had to receive trauma counselling as a result of the way in which he was treated after the disclosures had been made to the media; (v) the respondent having had to employ an attorney to defend him at the disciplinary hearing (where he was found not guilty), which cost him R77 000 and R100 000 to protect his interests and rights at the inquiry; to mention only a few (par 16, 19). The court then held that "a far more significant sum should be awarded as compensation for the indignity suffered, the extent of the publication of the attack on the respondent (publication being on national television) and the persistent, egregious nature of the attacks upon respondent which have been triggered because he had acted in the national interest" (par 22).

109 See, for e.g., John v Afrox Oxygen Ltd supra par 39, where the Labour Appeal Court held that Afrox's contention that the appellant was dismissed for incompatibility "is nothing short of fiction and the only probability is that the appellant's dismissal was in retaliation for her disclosure of the irregularities in the re-grading process". The court added that the appellant was dismissed for making a protected disclosure and as a result suffered occupational detriment. Consequently, her dismissal was automatically unfair and, as such, she was awarded compensation equivalent to 18 months' remuneration based on the gross salary she was earning at the time of her dismissal. Botha and Van Heerden point out that "the Companies Act does not specify the amount of compensation as in the case where an employee blows the whistle. This will obviously create problems with regard to whether it is fair to limit the amount of compensation in the case of an employee compared to that of other whistleblowers" (Botha and Van Heerden 2014 TSAR 351).

110 In terms of s 194(1) of the LRA, the amount of compensation should be "just and equitable".

111 S 194 of the LRA.

112 When awarding compensation, the court or arbitrator must use its discretion and be guided by the purposes of the Act together with the Constitution in order to calculate the amount fairly (see Victor and Picardi Rebel 2005 ILJ 2469 (CCMA) in this regard). In calculating the compensation, the court will be required to make a "rational assessment of facts that are relevant and have been properly tendered in evidence" (Brassey Employment and Labour Law (1999) A8:73). See, for e.g., Transnet Ltd v Commission for Conciliation, Mediation and Arbitration 2008 ILJ 1289 (LC) 1300d-e, where the court noted that s 194(1) of the LRA applies in circumstances where compensation is awarded for a procedurally unfair dismissal and held that "the compensation must be 'just and equitable' in all circumstances".

113 See Young v Coega Development Corporation (Pty) Ltd (2) 2009 ILJ 1786 (ECP), where the court held that the objects of the PDA would also be frustrated if the applicant was not reinstated, because, once an employee has on a prima facie basis established that he or 
dismissed employees, unless the dismissed employee does not wish to be reinstated, or the continuation of the employment relationship would be intolerable, or it is not reasonably practicable for the employer to reinstate an employee, or the dismissal was only procedurally unfair. ${ }^{11}$

\section{THE “EVADING” TAXPAYER'S RIGHTS}

\section{Introduction}

A person who blows the whistle regarding another's tax evasion assists SARS in fulfilling its duty to collect taxes effectively. In this regard, anonymity plays a pivotal role, as a potential whistle-blower might be less inclined to provide the information if his or her identity may be revealed to the person being accused of evading tax. ${ }^{115}$ As such, it is argued that the whistle-blower has a legitimate expectation of privacy regarding his or her identity. As highlighted in Bernstein $v$ Bester, ${ }^{116}$ whenever a person has a legitimate expectation of privacy, that person's right to privacy is affected when his or her privacy is invaded. On the other hand, the "evading" taxpayer has the right of access to information and to just administrative action, in terms of which he or she is empowered to seek certain information and request reasons. The question arises how these respective rights of whistle-blower and "evading" taxpayer should be balanced in the South African constitutional dispensation - or, simply put: whose rights prevail?

When dealing with this question, it must be borne in mind that no right in the Bill of Rights, which is contained in Chapter 2 of the Constitution, is absolute. ${ }^{117}$ Section 36 of the Constitution specifically provides that a right may be limited if the limitation is reasonable and justifiable. In establishing whether a right is reasonably and justifiably limited, a two-stage enquiry is used:

she suffered an occupational detriment, he or she is entitled to the full protection of the court. This protection includes reinstatement (1798a-c).

114 See also, for e.g., s 19(3) of the LRA which provides that, if a dismissal is automatically unfair or if a dismissal based on the employer's operational requirements is found to be unfair, the Labour Court may in addition make any other order that it considers appropriate in the circumstances. Grogan Workplace Law (2017) 180 is of the view that "[a] clue to the meaning of this somewhat cryptic provision is contained in a footnote [footnote $54 \mathrm{~s} 193$ of the LRA)". He adds that this explains why "in the case of a dismissal that constitutes an act of discrimination, for example, the court may issue an interdict obliging the employer to halt the discriminatory practice in addition to one of the other remedies provided for in the Act (180). S 193(3) of the LRA was intended to confer powers on the Labour Court to make orders that are ancillary to those of compensation, reinstatement and re-employment (see Whall v Brandadd Marketing (Pty) Ltd 199920 ILJ 1314 (LC) par 28).

115 According to South Africa Revenue Service "Report a Tax or Custom Crime" (2018-11-29) https://www.sars.gov.za/TargTaxCrime/ReportCrime/Pages/default.aspx (accessed 201905-28), a whistle-blower can select whether he or she wants to remain anonymous.

1161996 (2) SA 751 par 75.

117 Croome Taxpayers' Rights in South Africa: An Analysis and Evaluation of the Extent to Which the Powers of the South African Revenue Service Comply with the Constitutional Rights to Property, Privacy, Administrative Justice, Access to Information and Access to Courts (doctoral thesis, University of Cape Town) 200816. 
"The first enquiry is whether the ... provision limits a right in the Bill of Rights. If the provision limits a right in the Bill of Rights, this right must be clearly identified. The second enquiry is whether the limitation is reasonable and justifiable under section 36(1) of the Constitution."

In order to determine whether the limitation is reasonable and justifiable in terms of section 36(1), the following factors should be considered: the nature of the right; how important the purpose of the limitation is; the nature and extent of the limitation; the relationship between the limitation and its purpose; and whether there are less restrictive means available to accomplish the purpose of the limitation. ${ }^{119}$

This part first considers what an "evading" taxpayer's right of access to information in the event of whistle-blowing would entail. Thereafter, the right to just administrative action, more specifically the right to written reasons, ${ }^{120}$ is considered.

\section{The right of access to information}

\section{General}

Section 32 of the Constitution provides:

"(1) Everyone has the right of access to-

(a) any information held by the state; and

(b) any information that is held by another person and that is required for the exercise or protection of any rights.

(2) National legislation must be enacted to give effect to this right, and may provide for reasonable measures to alleviate the administrative and financial burden on the state."

Currie and De Waal note that the right of access to information generally stems from the notion that people are entitled to access information held by the State that has an impact on them. ${ }^{121}$ This ensures that government administration is open and accountable. ${ }^{12}$

The national legislation alluded to in section 32(2) of the Constitution is the Promotion of Access to Information Act (PAIA). ${ }^{123}$ In terms of PAIA, a person requesting information needs to request access to records from the relevant entity. ${ }^{124}$ "Records" in this regard refers to recorded information in the possession of the public body, and not necessarily created by the entity

118 Director of Public Prosecutions, Transvaal $v$ Minister for Justice and Constitutional Development 20094 SA 222 (CC) par 141.

119 S 36(1) (a)-(e) of the Constitution.

$120 \mathrm{~S} 33(2)$ of the Constitution provides that "[e]veryone whose rights have been adversely affected by administrative action has the right to be given written reasons".

121 Currie and De Waal The Bill of Rights Handbook (2013) 684.

122 Preamble to the Promotion of Access to Information Act 2 of 2000; Davis "Access to Information" in South African Constitutional Law: The Bill of Rights (2018) 26-2.

1232 of 2000. PAIA refers to access to information in relation to both public and private bodies, but as S 2(3) of PAIA stipulates that SARS is a public body for purposes of this Act, only the provisions pertaining to public bodies are considered in this article.

124 Robinson Access to Information (2016) 40. 
itself. ${ }^{125}$ Thus, the right to access information is rather the right to access records.

SARS must comply with a taxpayer's request to access records if two conditions are met. ${ }^{126}$ First, the taxpayer must have complied with the procedural requirements ${ }^{127}$ - that is, must have completed the prescribed form. ${ }^{128}$ Secondly, providing access to the record may not be prohibited in terms of Chapter 4 of Part 2 of PAIA. ${ }^{129}$ The grounds for refusal relevant for purposes of this article are: (i) protecting a third party's privacy; ${ }^{130}$ (ii) protecting certain records of SARS; ${ }^{131}$ and (iii) protecting certain confidential information pertaining to a third party. ${ }^{132}$ Before considering the grounds for refusal, it must be noted that section 28 of PAIA provides that the information that may be accessed must be severed from the parts in respect of which disclosure is refused. Thus, if a record contains any information that is subject to a ground of refusal, SARS would not be able to refuse disclosure of the entire record, but should disclose the information that is not subject to the ground for refusal.

\section{Grounds for refusal}

To protect the privacy of a third party, section 34(1) of PAIA prohibits any unreasonable disclosure of the personal information of a third party who is a natural person. Thus, the question that has to be asked, when a taxpayer wants access to information pertaining to a disclosure made by a third party to SARS, is whether the information the taxpayer seeks would amount to an unreasonable disclosure of personal information. As "personal information" is defined as "information about an identifiable individual", which, among others, includes "any identifying number, symbol or other particular assigned to the individual" 133 and a communication sent by the individual that is private or confidential in nature, ${ }^{134}$ it is submitted that the identity of the whistleblower would constitute "personal information". However, the information disclosed by the whistle-blower would not generally constitute "personal information", as it would relate to certain taxable transactions or events, and perhaps the personal information of the taxpayer (the requester), as opposed to personal information of the third party. Based on this, only the identity of the whistle-blower would fall within the ambit of section 34(1) of PAIA.

Par (c) of the "personal information" definition in s 1 of PAIA. In terms of the Schedule to the Protection of Personal Information Act 4 of 2013, par (c) of the definition of personal information, as contained in s 1 of PAIA, will be amended to include the "email address, physical address, telephone number, location information, online identifier or other particular assigned to the person".

134 Par (f) of "personal information" definition in s 1 of PAIA.
} 
Thus, in order for SARS to refuse to reveal the identity of the whistleblower in terms of section 34(1), it must be determined whether revealing the identity of the whistle-blower would be an unreasonable disclosure. This requires a consideration of the right to privacy as provided for in section 14 of the Constitution. ${ }^{135}$ With regard to the right to privacy when disclosing information, it must be borne in mind that,

"[w]herever a person has the ability to decide what he or she wishes to disclose to the public and the expectation that such a decision will be respected is reasonable, the right to privacy will come into play".

As a whistle-blower would usually not want his or her identity disclosed, he or she would have a reasonable expectation that his or her identity would be treated as confidential. As such, his or her identity should be protected in terms of the right to privacy. This means that, in general, revealing the identity of the whistle-blower would constitute an unreasonable disclosure of personal information as envisaged in section 34(1) of PAIA. Nonetheless, section $34(2)(a)$ provides that the personal information of a third party may be disclosed where the third party has consented thereto in terms of section 48 of PAIA. As a result, the identity of the whistle-blower may only be revealed where the whistle-blower has provided written consent that his or her personal information may be disclosed. ${ }^{137}$ It is, however, difficult to envisage a situation where a whistle-blower would in fact provide the required consent for his or her identity to be revealed.

As regards the second relevant ground for refusal, a request for access to a record must be refused if the record held by SARS contains information that is held "for the purposes of enforcing legislation concerning the collection of revenue" ${ }^{138}$ As neither this phrase nor any components thereof, except for "revenue", ${ }^{139}$ is defined, it is uncertain what information must be refused in terms of this ground. In this respect, various scholars acknowledge the link between this ground for refusal and the duty of SARS to preserve the secrecy of information as provided for in Chapter 6 of the TAA. ${ }^{140}$ Accordingly, it is submitted that some assistance as to what information could be subject to refusal in terms of section 35 of PAIA may be obtained from the relevant provisions in the TAA.

Section $67(1)$ of the TAA prohibits the disclosure of taxpayer information and confidential information held by SARS. Taxpayer information relates to

135 Centre for Social Accountability v Secretary of Parliament [2011] 4 All SA 181 (ECG) par 63. See, also, Currie and Klaaren The Promotion of Access to Information Act Commentary (2002) 122 in this regard.

136 The Investigating Directorate: Serious Economic Offences v Hyundai Motor Distributors (Pty) Ltd In re: Hyundai Motor Distributors (Pty) Ltd v Smit NO [2000] JOL 7338 (CC) par 16.

137 Ss $48(1)(b)$ and $48(2)(b)$ of PAIA.

$138 \mathrm{~S} 35(1)$ of PAIA.

139 S 35(1) of PAIA refers to "revenue" as defined in s 1 of the South African Revenue Service Act 34 of 1997. In turn, that section defines "revenue" as "income derived from taxes, duties, levies, fees, charges, additional tax and any other moneys imposed in terms of legislation, including penalties and interest in connection with such moneys".

140 Currie and Klaaren The Promotion of Access 122; Croome and Olivier Tax Administration 2ed (2015) 620; Arendse, Williams and Klue Silke on Tax Administration (OS 2018) 11-1. 
information in respect of a taxpayer obtained by SARS or information provided by a taxpayer, ${ }^{141}$ while confidential information includes, inter alia, information supplied by a third party the disclosure of which by SARS could reasonably be expected to negatively influence the supply of similar information or information by the specific third party in future.

Nonetheless, section 73 of the TAA allows for disclosure to a taxpayer of his or her own records. ${ }^{143}$ These "own records" include recorded details of an assessment or decision, information submitted by the taxpayer or on behalf of the taxpayer, any other information pertaining to the tax affairs of the taxpayer, and information on which an assessment was based that does not fall within the ambit of confidential information held by SARS. ${ }^{144}$ Thus, it is clear that, in terms of section 73 of the TAA, the duty of secrecy does not relate to the tax affairs of the specific taxpayer. Similarly, in terms of section 35(2) of PAIA, SARS would not be able to refuse the disclosure of information pertaining to the requester taxpayer on the basis of section 35(1) of PAIA.

An aspect that is not so clear is whether SARS may refuse the disclosure of "own records" sought by the taxpayer when the information was supplied confidentially by a whistle-blower and it is reasonably expected that such disclosure would negatively influence the supply of similar "whistle-blowing information" overall or from the specific whistle-blower in future. Section 73 read with section $68(1)(c)$ of the TAA specifically excludes this type of information from disclosure. However, section 35 of PAIA provides no indication whether information that relates to the requester but is considered to be confidential information held by SARS must not be disclosed in terms of this specific ground for refusal. Section 5 of PAIA does give some guidance on how to deal with this aspect, as it provides that PAIA takes preference over other legislation that restricts or prohibits the right of access to information. Accordingly, SARS may not deny access to confidential information based on section 35 of PAIA if it pertains to the taxpayer. This means that a taxpayer is entitled to information pertaining to his or her own tax affairs, irrespective of whether it constitutes confidential information held by SARS. However, as the identity of a whistle-blower does not constitute taxpayer information from the requester's perspective, SARS should reject a request to reveal the identity of a whistle-blower.

The last relevant ground for refusal is provided for in section 37 of PAIA and relates to certain confidential information. First, the relevant subsection prohibits the disclosure of a record if the disclosure would violate a duty of confidence agreed upon by the public body - in this instance SARS - and a third party. ${ }^{145}$ Although it is apparent that the aim of this subsection is to protect confidential information, ${ }^{46}$ the subsection only relates to a duty that is created in terms of an agreement. For this reason, a duty to treat

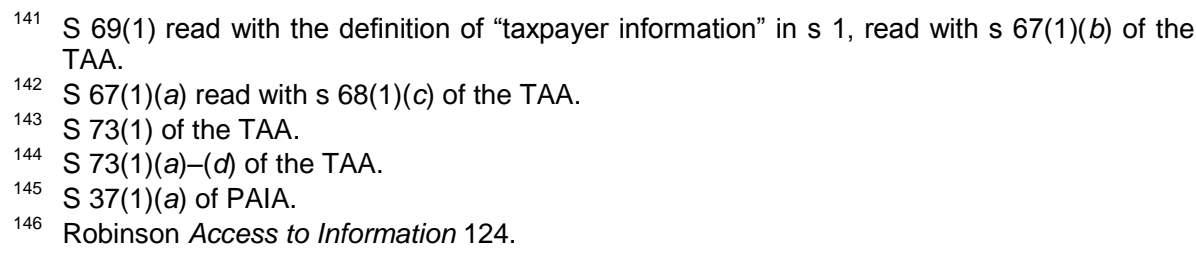


information as confidential that is created in terms of legislation would not be protected by this subsection ${ }^{147}$ and other grounds for refusal would have to be considered to protect that specific type of confidential information.

Secondly, subsection $37(1)(b)$ of PAIA stipulates that a public body may refuse to disclose information provided confidentially by a third party:

“(i) the disclosure of which could reasonably be expected to prejudice the future supply of similar information, or information from the same source; and

(ii) if it is in the public interest that similar information, or information from the same source, should continue to be supplied".

In order for this subsection to apply, the information must be supplied in confidence. This requires that there must have been a reasonable expectation of confidence. ${ }^{148}$ As such, the content of the information, the purpose thereof, and the conditions in terms of which it was supplied should be considered. ${ }^{149}$ Furthermore, for this subsection to apply, the information should constitute confidential information held by SARS. ${ }^{150}$ As disclosure of the information can easily be expected to impact the future supply of similar information, both in quantity and quality, it is aptly required that the continued future supply should be in the public interest. Thus, information that assists public bodies in fulfilling their functions would meet this requirement, whereas information that is available from non-confidential sources would not. ${ }^{15}$

Turning to the specific instance where a whistle-blower has provided confidential information to SARS about another person evading taxes, it is submitted that: (i) the whistle-blower will, as a rule, have an expectation of privacy; (ii) any disclosure of this information to the taxpayer could result in potential whistle-blowers not providing similar information in the future for fear of reprisals if their identities be revealed by the disclosure of this information; and (iii) it is in the public interest that whistle-blowers continue to inform SARS about evading taxpayers, as the revenue collected from this could be used to realise the socio-economic rights of the public in general. Based on this, when a whistle-blower provides information pertaining to the tax evasion of another, it would fall within the ambit of this ground for refusal.

\section{Public-interest override}

For purposes of this article, it is important to note that, in instances of the unreasonable disclosure of the personal information of a third party, ${ }^{152}$ or of a confidential agreement, ${ }^{153}$ or of information that would have an effect on

\footnotetext{
Currie \& Klaaren The Promotion of Access 153

Currie \& Klaaren The Promotion of Access 156

Ibid.

$\mathrm{S} 68(1)(c)$ of the TAA

Currie \& Klaaren The Promotion of Access 158.

52 In terms of $s$ 34(1) of PAIA.

153 In terms of $\mathrm{s} 37(1)($ a) of PAIA. For a further discussion of how this principle applies in cases of mandatory grounds for refusal, see Currie \& Klaaren The Promotion of Access 108.
} 
the future supply of similar information, grounds for refusal apply. ${ }^{154}$ SARS must, however, take into account the "public-interest override". ${ }^{155}$ If it applies, then the public body must grant access to the record concerned. ${ }^{156}$

Section 46 of PAIA stipulates the following in this regard:

"Despite any other provision of this Chapter, the information officer of a public body must grant a request for access to a record of the body ... if-

(a) the disclosure of the record would reveal evidence of-

(i) a substantial contravention of, or failure to comply with, the law; ... (ii) $\ldots$; and

(b) the public interest in the disclosure of the record clearly outweighs the harm contemplated in the provision in question."

When a whistle-blower has blown the whistle on tax evasion, it is clear that disclosing that information to a requester would reveal evidence of a substantial contravention, as section 235(1) of the TAA specifically labels tax evasion a criminal offence. Thus, the area of contention would be whether the public interest in disclosing the information associated with an offence outweighs the harm of disclosing the information. Possible harm if the information is disclosed includes similar information not being provided in future or the whistle-blower being subject to victimisation or reprisals.

In considering the "public-interest override" in relation to the "personal information of a third party" ground for refusal, the court in Centre for Social Accountability $v$ Secretary of Parliament indicated that it refers to those instances where society does not consider an expectation of privacy to be reasonable. ${ }^{157}$ In this regard, the expectations of society, or the public interest, do not relate to "idle gossip, or public curiosity about what in truth are trivialities". ${ }^{158}$

Although it may be in the public interest that a taxpayer is aware of what information led to an additional assessment, disclosing information that could reveal the identity of the whistle-blower may infringe upon a reasonable expectation of privacy. Although a straightforward disclosure of the whistle-blower's identity would surely serve no legitimate purpose and cannot be seen to be in the public interest, it is more difficult to determine when it is in the public interest to disclose information relating to an additional assessment if it could indirectly reveal the identity of the whistleblower. It is submitted that the facts of each case would determine whether there is a close-enough identifying link between the information and the whistle-blower's identity.

As the "confidential agreement" ground for refusal also takes into account the whistle-blower's expectation of privacy, the same approach of identifying whether the public interest overrides the ground for refusal should be adopted.

\footnotetext{
$S 33(1)(a)$ read with $s 46$ of PAIA.

S 33(1)(b) read with $S 46$ of PAIA.

56 Centre for Social Accountability v Secretary of Parliament supra par 58-61.

157 Centre for Social Accountability v Secretary of Parliament supra par 99-100.

158 Corporate Officer of the House of Commons $v$ Information Commissioner [2009] 3 All ER 403 408. This matter was quoted with approval in Centre for Social Accountability $v$ Secretary of Parliament supra par 102.
} 
Where the effect of a disclosure on the future supply of information must be established (in the context of a decision whether to refuse to disclose information), the question is first whether such a future supply would be in the public interest. Then, the public interest is again considered as part of the override to ensure that information is disclosed when it is in the public interest. As a result, the importance of the type of information is juxtaposed with the importance of disclosing the particular record. It is submitted that the continued supply of information for the purpose of revealing tax evasion would outweigh providing sensitive information that could connect the whistle-blower to the disclosure.

\section{Concluding remarks on the right of access to information}

From the discussion above, it is evident that the right of access to information is limited by the grounds for refusal when it relates to the identity of the whistle-blower. However, when the information sought by the requester taxpayer could indirectly reveal the identity of the whistle-blower, the possible legitimate refusal thereof is not so evident.

The public-interest override highlights the public interest as a key factor in determining whether or not to disclose certain information. This is not the only area where the public interest is considered in relation to whistleblowing. As indicated earlier, ${ }^{159}$ the public interest is also paramount when establishing whether a whistle-blower has made a protected disclosure in terms of the PDA.

\section{The right to just administrative action}

\section{General}

Another avenue a taxpayer could pursue to gain access to the information that has led SARS to investigate possible tax evasion is the right to just administrative action as provided for in section 33 of the Constitution. Section 33 stipulates:

“(1) Everyone has the right to administrative action that is lawful, reasonable and procedurally fair.

(2) Everyone whose rights have been adversely affected by administrative action has the right to be given written reasons ..."

Moreover, section 33(3) provides that national legislation must be enacted to give effect to this right. As a consequence, the Promotion of Administrative Justice Act (PAJA) ${ }^{160}$ was enacted.

\footnotetext{
See 2.3 above.

1602 of 2000 .
} 


\section{Just administrative action}

It is necessary to establish what would constitute "administrative action"161 in the context of a whistle-blowing disclosure on alleged tax evasion. Section 1 of PAJA defines "administrative action" as:

"any decision taken, or any failure to take a decision, by-

(a) an organ of state, when-

(i) exercising a power in terms of the Constitution or a provincial constitution; or

(ii) exercising a public power or performing a public function in terms of any legislation; ...

which adversely affects the rights of any person and which has a direct, external legal effect."

The following elements can be extracted from this definition: (i) a decision, or failure to make a decision; (ii) by an organ of state; (iii) a person's right(s) must be adversely affected; and (iv) it should have a direct, external legal effect.

PAJA defines "decision" as "any decision of an administrative nature, proposed to be made, or required to be made, as the case may, under an empowering provision". ${ }^{163}$ Two further characteristics may be gleaned from

161 Corder ("Administrative Justice" in South African Constitutional Law: The Bill of Rights (last updated October 2015) Lexis Nexis Internet version par 27.3.1) points out that the question as to what administrative action is a delineation question when dealing with administrative law in any modern system.

162 Par $(b)$ of the definition of administrative action relates to persons other than an organ of state. As the present article is concerned with SARS, an organ of state, par $(b)$ is irrelevant. The following actions are explicitly excluded from the definition of administrative action contained in $\mathrm{S} 1$ of PAJA:

"(aa) the executive powers or functions of the National Executive, including the powers or functions referred to in sections $79(1)$ and $(4), 84(2)(a),(b),(c),(d),(f),(g),(h)$, (i) and $(k), 85(2)(b),(c),(d)$ and $(e), 91(2),(3),(4)$ and (5), 92(3), 93, 97, 98, 99 and 100 of the Constitution;

$(b b)$ the executive powers or functions of the Provincial Executive, including the powers or functions referred to in sections $121(1)$ and $(2), 125(2)(d),(e)$ and $(f), 126,127(2)$, $132(2), 133(3)(b), 137,138,139$ and $145(1)$ of the Constitution;

(cc) the executive powers or functions of a municipal council;

(dd) the legislative functions of Parliament, a provincial legislature or a municipal council;

(ee) the judicial functions of a judicial officer of a court referred to in section 166 of the Constitution or of a Special Tribunal established under section 2 of the Special Investigating Units and Special Tribunals Act, 1996 (Act No. 74 of 1996), and the judicial functions of a traditional leader under customary law or any other law;

(ff) a decision to institute or continue a prosecution;

(gg) a decision relating to any aspect regarding the nomination, selection, or appointment of a judicial official or any other person, by the Judicial Service Commission in terms of any law;

(hh) any decision taken, or failure to take a decision, in terms of any provision of the Promotion of Access to Information Act, 2000; or

(ii) any decision taken, or failure to take a decision, in terms of section 4(1)."

163 S 1 of PAJA. The decision specifically includes a decision relating to-

"(a) making, suspending, revoking or refusing to make an order, award or determination;

(b) giving, suspending, revoking or refusing to give a certificate, direction, approval, consent or permission; 
this definition - namely that the decision must be administrative in nature and that it must be made under an empowering provision. In the absence of a statutory definition of "administrative nature", the court in The President of the Republic of South Africa $v$ South African Rugby Football Union ${ }^{164}$ held that "administrative in nature" does not refer to:

"whether the action concerned is performed by a member of the executive arm of government. What matters is not so much the functionary as the function. The question is whether the task itself is administrative or not."

Burns and Beukes state that an action would be administrative in nature when it is of a public law ${ }^{166}$ nature and a relationship of inequality exists. This means that the action is not based on an equal private footing, but is rather due to one legal subject standing in a position of authority over another legal subject. ${ }^{167}$ As regards the second characteristic, section 1 of PAJA defines "empowering provision" as "a law, a rule of common law, customary law or an agreement, instrument or other document". ${ }^{168}$ Consequently, when SARS issues an additional assessment to correct the prejudice SARS or the fiscus has suffered due to tax evasion that has been exposed by a whistle-blower, this would constitute a "decision" in terms of PAJA.

The element requiring that the person carrying out the administrative action - namely, SARS - be an organ of state ${ }^{169}$ will also be complied with in the tax evasion whistle-blower instance. Furthermore, an action will only be an administrative action if it adversely affects the rights of any person. ${ }^{170}$ Currie and Klaaren note that this element is concerned with the consequence of the administrative action. ${ }^{171}$ According to them, "adversely" refers to imposing a burden. ${ }^{172}$ They understand it to be a burden when a person has to do or tolerate something, when a person's right is removed, or

(c) issuing, suspending, revoking or refusing to issue a licence, authority or other instrument;

(d) imposing a condition or restriction;

(e) making a declaration, demand or requirement;

(f) retaining, or refusing to deliver up, an article; or

(g) doing or refusing to do any other act or thing of an administrative nature, and a reference to a failure to take a decision must be construed accordingly."

See, also, Hoexter Administrative Law in South Africa (2012) 197.

164 (2000) 1 SA (CC).

165 The President of the Republic of South Africa $v$ South African Rugby Football Union supra par 141.

166 Burns and Beukes Administrative Law Under the 1996 Constitution (2003) 22. Burns and Beukes (22) explain that this should be distinguished from, for instance, a contract of sale concluded between a municipality and a private person, as that relates to private law as opposed to public law.

167 Burns and Beukes Administrative Law 87-88.

168 Hoexter Administrative Law 205 indicates that this concept is defined rather broadly.

169 See s 4(2) of the South African Revenue Service Act 34 of 1997.

170 See De Ville Judicial Review of Administrative Action in South Africa (2003) 51-54 for a discussion of the history of this requirement.

171 Currie and Klaaren The Promotion of Administrative Justice Act Benchbook (2001) 75.

172 Ibid. 
when an adverse determination is made in relation to a person's rights. ${ }^{173}$ Hoexter comments that, owing to the "adversely" requirement, a person who has benefited from administrative conduct will not fall within the definition of administrative action. ${ }^{174}$

The concept "affects" may be construed in two ways. "Affects" could mean the deprivation of a person's established rights, ${ }^{175}$ or it could relate to determining a person's rights. ${ }^{176}$ Hoexter indicates that PAJA does not provide a conclusive answer and, as such, the wording of section 33 of the Constitution should clarify how "affects" is to be construed. ${ }^{177}$ Furthermore, she states that, because administrative action in section 33 of the Constitution does not contain restrictions, the definition of administrative action in PAJA should reflect the broader meaning of administrative action as envisaged in section 33 of the Constitution. ${ }^{178}$ Consequently, she argues that "affects" should refer to both the deprivation of established rights and the determination of rights. ${ }^{179}$ Devenish, Govender and Hulme rely on section 39(2) of the Constitution to assign the liberal meaning of "influence" to the concept "affects", instead of a literal meaning. ${ }^{180}$ Therefore, they are also of the opinion that "affects" should include the determination of rights.

The last important concept to consider under the element of "adversely affects the rights of any person" is "rights". Importantly, the "rights" do not necessarily have to be the rights of the applicant, as the provision clearly states the "rights of any person". ${ }^{181}$ Also, the concept "rights" does not refer only to constitutional rights. Other statutory or common-law rights are also included. $^{182}$

73 Ibid.

174 Hoexter Administrative Law 227

175 Currie and Klaaren Benchbook 76; Hoexter Administrative Law 221.

176 Currie and Klaaren Benchbook 77; Hoexter Administrative Law 221.

177 Hoexter Administrative Law 221. Currie and Klaaren Benchbook 77 hold a similar view, as they point out that PAJA is intended to give effect to the constitutional right contained in s 33(1) of the Constitution. Hoexter Administrative Law 221 (fn 390) states that the term "rights" is used instead of "interest", and "legitimate expectations" to point towards established rights being required. However, she considers "decision" to include refusing to give permission or issue a licence, which is indicative of an interpretation in terms of which "affects" relates to determining rights.

178 Hoexter "Just Administrative Action" in Currie and De Waal (eds) Bill of Rights Handbook 661.

179 In addition to relying on s 33 of the Constitution, Hoexter, in Currie and De Waal Bill of Rights Handbook 661 fn 85, argues that if "affects" connoted a deprivation of existing rights, explicit wording such as "deprivation" or "existing rights" should have been used instead of "affecting" and "rights".

180 Devenish, Govender and Hulme Administrative Law and Justice in South Africa (2001) 127.

181 Own emphasis added.

182 Currie and Klaaren Benchbook (2001) 79-80; Burns and Beukes Administrative Law 29. Burns and Beukes (27) indicate that, based on the common-law doctrine of legitimate expectations, the rights referred to in PAJA are expanded to include legitimate expectations. S 3(1) of PAJA also provides that administrative action that substantially and adversely affects the rights or legitimate expectations of a person must be procedurally fair. See, also, Premier, Mpumalanga v Executive Committee, Association of State-Aided Schools, Eastern Transvaal 1999 (2) BCLR 151 (CC) par 41; Joseph v City of Johannesburg 2010 (3) BCLR 212 (CC) par 41 in this regard. 
The last two elements for a decision to constitute administrative action namely, "adversely affecting rights" and having "direct external legal effect" appear to be closely related. ${ }^{183}$ More specifically, the concept "legal effect" overlaps with the requirement of adversely affecting rights. ${ }^{184}$ "Legal effect", like "adversely affecting rights", implies that someone's rights must be determined, changed or withdrawn.

"Direct effect" in the concept "direct external legal effect" alludes to finality, ${ }^{186}$ as it appears to underpin the idea that an administrative decision must be "ripe" before it can be reviewed. ${ }^{187}$ This common-law idea entails that a complainant should approach a court when the transgression or decision is final. This ensures that a court does not consider "half-formed" decisions. ${ }^{188}$

Finally, the concept "external effect" entails that the decision must affect someone other than the organ of state that made the decision. ${ }^{189}$

Overall, when SARS issues an assessment, this would constitute administrative action. ${ }^{190}$ Similarly, when SARS issues an additional assessment to correct the prejudice SARS or the fiscus ${ }^{191}$ has suffered owing to tax evasion that has now been exposed by a whistle-blower, this would be administrative action as defined in PAJA. Consequently, the "evading" taxpayer would be able to rely on his or her right to just administrative action that is given effect to by PAJA.

This means that the taxpayer has the right to request reasons for the specific assessment. ${ }^{192}$ These reasons should place the recipient thereof in the position to say:

"Even though I may not agree with it, I now understand why the decision went against me. I am now in a position to decide whether that decision has involved an unwarranted finding of fact, or an error of law, which is worth challenging."

183 The Parliamentary Committee added this last element at a late stage. See Pfaff and Schneider "The Promotion of Administrative Justice Act From a German Perspective" 2001 17 SAJHR 59 for further reading relating to the history of this element, which is derived from art 35 of the German Federal Law of Administrative Procedure of 1976.

184 Currie and Klaaren Benchbook 75; Burns and Beukes Administrative Law 27, 31; De Ville Judicial Review 55; Hoexter Administrative Law 229.

185 Currie and Klaaren Benchbook 82.

186 Currie and Klaaren Benchbook 82; Burns and Beukes Administrative Law 30; De Ville Judicial Review 55; Hoexter Administrative Law 231.

187 Hoexter Administration Law in South Africa (2007) 206.

188 Hoexter Administrative Law in South Africa 585-587.

189 Currie and Klaaren Benchbook 82; Burns and Beukes Administrative Law 3.

190 Croome Taxpayers' Rights in South Africa 211.

191 See $s 92$ of the TAA in this regard.

192 S 33(2) of the Constitution; s 5(1) of PAJA; Rule 6 of the Rules promulgated under s 103 of the TAA.

193 In Re Palmer and Minister for the Capital Territory (1978) 23 ALR 196 206, and quoted with approval in the South African case of Minister of Environmental Affairs and Tourism $v$ Phambili Fisheries (Pty) Ltd [2003] 2 All SA 616 (SCA) par 40. 
Thus, in casu, the reasons should explain why SARS issued an additional assessment. It is submitted that this means that SARS will need to indicate the basis for the conclusion that there has been tax evasion but not the identity of the whistle-blower.

\section{THE POSITION IN THE USA REGARDING FINANCIAL/MONETARY INCENTIVES FOR TAX WHISTLE-BLOWERS}

It is important to note that, in light of the discussion above, due cognisance should be taken of developments in the US regarding tax whistle-blower programmes where financial incentives are granted to whistle-blowers. In the US, the Securities and Exchanges Commission (SEC) ${ }^{194}$ has established a whistle-blower programme in terms of which the SEC is authorised to pay, ${ }^{195}$ and award, between 10 and 30 per cent of the amounts collected if an "eligible whistle-blower" voluntarily provides original information ${ }^{196}$ that leads to a successful enforcement action with monetary sanctions exceeding USD 1 million. ${ }^{197}$ Section 7623 of the Internal Revenue Code (IRC or "Code")

194 In the UK, banks, building societies, insurance companies and large investment firms are required by law to establish an independent whistle-blowing channel in terms of which staff members may make disclosures to a senior individual who has been appointed as a whistle-blower champion and thereby ensure the effectiveness of whistle-blowing arrangements. This is in line with the UK's PIDA of 1998. On 15 January 2014, the Canada Revenue Agency (CRA) announced the opening of its own Offshore Tax Informant Program (OTIP), which is Canada's tax whistle-blower programme designed to target major cases of international tax evasion or avoidance. Only individuals can participate in OTIP and are eligible as informants to rewards of between 5 and 15 per cent of the federal tax collected. Whistle-blowers will only be paid under OTIP once the taxpayer's appeal rights have been exhausted and the amount owing is collected. See, in this regard, Farag and Dworkin "A Taxing Process: Whistleblowing Under the I.R.S. Reward Program" 2016 XXVI Southern Law Journal 19 39-40.

195 See, also, in this regard Transparency International Best Practice 56 Principle 23, which provides for reward systems for whistle-blowers as follows: "[l]f appropriate within the national context, whistleblowers may receive a portion of any funds recovered or fines levied as a result of their disclosure. Other rewards or acknowledgements may include public recognition or awards (if agreeable to the whistleblower), employment promotion, or an official apology for retribution."

196 See, in this regard, US Securities and Exchange Commission "Office of the Whistleblower" (undated) https://www.sec.gov/whistleblower (accessed 2018-12-30).

197 See Dodd-Frank Act § 922(a); 15 U.S.C.A. § 78u-6 (2010). See 15 U.S.C. § 78u-6(b)(1), which provides as follows:

"In any covered judicial or administrative action, or related action, the Commission ... shall pay an award or awards to 1 or more whistleblowers who voluntarily provided original information to the Commission that led to the successful enforcement of the covered judicial or administrative action, or related action, in an aggregate amount equal to-

(A) not less than 10 percent, in total, of what has been collected of the monetary sanctions imposed in the action or related actions; and

(B) not more than 30 percent, in total, of what has been collected of the monetary sanctions imposed in the action or related actions."

See, also, Code s 7623(a), which provides that the Secretary is authorised to pay such sums as he or she deems necessary for detecting underpayments of tax, or detecting and bringing to trial and punishment persons guilty of violating the internal revenue laws or conniving at the same, in cases where such expenses are not otherwise provided for by law. Any amount payable under the preceding will be paid from the proceeds of amounts collected by reason of the information provided, and any amount so collected will be 
provides for financial incentives for tax whistle-blowing as follows: a discretionary award is provided for under section 762(a) and a mandatory award is provided for under section 7623(b). ${ }^{198}$ Section 7623 (b) provides that, if the Secretary proceeds with any administrative or judicial action ${ }^{199}$ based on information brought to the Secretary's attention by an individual, such individual shall receive as an award at least 15 per cent, but not more than 30 per cent, of the proceeds collected as a result of the action or from any settlement in response to such action. ${ }^{200}$ The determination of the amount of such award by the Office of the Whistleblower will depend on the extent to which the individual substantially contributed to such action. ${ }^{201}$ Whistle-blowers are eligible to receive a financial award "based on the amount of tax revenue eventually collected from the information provided". ${ }^{202}$ Since 2007, the Office of the Whistleblower has made awards in the amount of USD 499174673 based on the collection of USD 3609932724 . In the 2017 financial year (in which 27 of the award payments made involved Code section 7623(b) claims), the Internal Revenue Service (IRS) made 242 awards $^{203}$ totalling USD 33979873 prior to the sequestration reduction. The total award amount represented 17.8 per cent of the total amount collected. $^{204}$ The Office of the Whistleblower takes into account positive and negative factors in determining the amount of an award. Positive factors ${ }^{205}$ include (but are not limited) to the following:

(i) the whistle-blower acted promptly to inform the IRS or the taxpayer of the tax non-compliance;

(ii) the information provided identified an issue of a type previously unknown to the IRS;

(iii) the information provided identified taxpayer behaviour that the IRS was unlikely to identify or that was particularly difficult to detect through the IRS's exercise of reasonable diligence;

available for such payments. This section was enacted as part of the Tax Relief and Health Care Act of 2006.

198 S 7623(b) awards are limited to individuals. See Treas. Reg. § 301.7623-4(b)(1) (as amended in 2014) in this regard.

199 See, in this regard, Code s 7623(a).

200 Goulder Views From the Fourth Estate (2018) 2.

201 See, in this regard, Code s 7623(b).

202 Goulder Views From the Fourth Estate 2.

203 Treas. Reg. $\S 301.7623-2$ (d) (as amended in 2014) provides that awards are payable on the "collected proceeds", which is the money that the IRS collected directly from taxpayers based on information supplied by the whistle-blower. Collected proceeds include: "tax, penalties, interest, additions to tax and additional amounts collected by reason of the information provided; amounts collected prior to receipt of the information if the information provided results in the denial of a claim for refund that otherwise would have been paid; and a reduction of an overpayment credit balance used to satisfy a tax liability incurred because of the information provided."

204 See, in this regard, IRS "Whistleblower Program, Fiscal Year 2017, Annual Report to Congress, Doc 2018-778" (undated) https://www.irs.gov/pub/whistleblower/fy17 wo annual report final.pdf (accessed 2018-12-30) 9. The IRS has approved roughly $\$ 500$ million in awards, which amounts roughly to an average of around 17 per cent of successful recoveries. See, in this regard, Goulder Views From the Fourth Estate 2.

205 See, in this regard, Treas. Reg. § 301.7623-4(b)(1) (as amended in 2014); Farag and Dworkin 2016 Southern Law Journal 30. 
(iv) the information provided thoroughly presented the factual details of tax non-compliance in a clear and organised manner, particularly if the manner of the presentation saved the IRS work and resources;

(v) the whistle-blower (or the whistle-blower's legal representative, if any) provided exceptional cooperation and assistance during the pendency of the actions;

(vi) the information provided identified assets of the taxpayer that could be used to pay liabilities, particularly if the assets were not otherwise known to the IRS;

(vii) the information provided identified connections between transactions, or parties to transactions, that enabled the IRS to understand tax implications that might not otherwise have been understood by the IRS; and

(viii) the information provided had an impact on the behaviour of the taxpayer, for example by causing the taxpayer to correct a previously reported improper position.

Negative factors ${ }^{206}$ include, but are not limited to, the following:

(i) the whistle-blower delayed informing the IRS after learning the relevant facts, particularly if the delay adversely affected the IRS's ability to pursue an action or issue;

(ii) the whistle-blower contributed to the underpayment of tax or tax noncompliance identified;

(iii) the whistle-blower directly or indirectly profited from the underpayment of tax or tax non-compliance identified, but did not plan and initiate the actions that led to the underpayment of tax or actions described in section $7623(\mathrm{a})(2)$;

(iv) the whistle-blower (or the whistle-blower's legal representative, if any) negatively affected the IRS's ability to pursue the action(s), for example by disclosing the existence or scope of an enforcement activity;

(v) the whistle-blower (or the whistle-blower's legal representative, if any) violated instructions provided by the IRS, particularly if the violation caused the IRS to expend additional resources;

(vi) the whistle-blower (or the whistle-blower's legal representative, if any) violated the terms of the confidentiality agreement described in section 301.7623-3(c)(2)(iv);

(vii) the whistle-blower (or the whistle-blower's legal representative, if any) violated the terms of a contract entered into with the IRS pursuant to section 301.6103(n)-2; and

(viii) the whistle-blower provided false or misleading information or otherwise violated the requirements of section $7623(b)(6)(C)$ or section $301.7623-$ $1(c)(3)$.

Under the Wall Street Reform and Consumer Protection Act of 2010 (Dodd-Frank Act), ${ }^{207}$ no employer may, under the whistle-blower protection

206 See, in this regard, Treas. Reg. § 301.7623-4(b)(2) (as amended in 2014); Farag and Dworkin 2016 Southern Law Journal 31.

207 This Act was passed by Congress in 2010 in response to the fraud that led to the financial crisis in 2008 and provides financial incentives to those with knowledge of securities fraud 
provision, discharge, demote, suspend, threaten or harass, directly or indirectly, or in any other manner discriminate against a whistle-blower in the terms or conditions of employment because of any lawful act done by the whistle-blower. If individuals face reprisals by their employer, they may bring a private right of action in the federal court on the grounds of such behaviour. Section 748 of the Dodd-Frank Act ${ }^{208}$ also provides for powerful monetary incentives for whistle-blowers to report commodity law violations to the Commodity Futures Trading Commission (CFTC or "Commission"), and amended the Commodity Exchange Act (CEA) by adding a new section 23 entitled "Commodity Whistleblower Incentives and Protections". Similarly, section 922 of the Dodd-Frank Act provides for "powerful monetary incentives" 209 for whistle-blowers to report securities law violations to the SEC and defines a whistle-blower as "any individual who provides, or 2 or more individuals acting jointly who provide, information relating to a violation of the securities laws to the Commission, in a manner established, by rule or regulation, by the Commission". ${ }^{210}$ To be eligible for an award under the SEC bounty provision, the whistle-blower must: (i) voluntarily provide the Commission, (ii) with original information, ${ }^{211}$ (iii) that leads to the successful enforcement by the Commission of a federal court or administrative action, (iv) in which the Commission obtains monetary sanctions totalling more than USD 1 million. ${ }^{212}$ The CFTC announced in July 2018 that it had made the

to come forward and alert the SEC. It should be noted that the Dodd-Frank programme is "extremely similar" to the IRS's tax Whistleblower Program. See, in this regard, Farag and Dworkin 2016 Southern Law Journal 36.

208 Codified at 7 U.S.C. $\$ 26$.

209 Rosenberg and Phillips "Whistleblower Claims Under the Dodd-Frank Wall Street Reform and Consumer Protection Act: The New Landscape" (undated) https://www.nysba.org/ Sections/Labor_and_Employment/Labor_PDFs/LaborMeetingsAssets/Whistleblower_Claim s_Under_Dodd_Frank.html (accessed 2018-12-30) 2.

210 See 15 U.S.C. $\S 78 u-6(a)(6)$ in this regard.

211 Original information is defined as information that is:

"(A) derived from the independent knowledge or analysis of a whistleblower;

(B) not known to the SEC from any other source, unless the whistleblower is the original source of the information;

(C) not exclusively derived from an allegation made in a judicial or administrative hearing, in a governmental report, hearing, audit, or investigation, or from the news media, unless the whistleblower is a source of the information; and

(D) provided to the SEC for the first time after July 21, 2010."

See 15 U.S.C. $\S 78$ u-6(a)(3); 17 C.F.R. $\S 240.21 \mathrm{~F}-4(\mathrm{~b})$ in this regard. In this context, "independent knowledge" is factual information in the whistle-blower's possession that is not derived from publicly available sources and which a whistleblower may gain independent knowledge of from his or her experiences, communications, and observations in business or social interactions. In turn, "independent analysis" means the whistle-blower's own analysis, whether done alone or with others - that is, the whistle-blower's examination and evaluation of information that may be publicly available, but which reveals information that is not generally known or available to the public. See 17 C.F.R. $\S 240.21 F-4(b)(2)-(3)$; Rosenberg and Phillips "Whistleblower Claims" 5.

212 See 15 U.S.C. $\S 78$ u(b); 17 C.F.R. $\S 240.21 \mathrm{~F}-3(\mathrm{a})$. Factors that may increase the amount of a whistle-blower's award include the significance of the information provided by the whistle-blower; assistance provided by the whistle-blower; law enforcement interest; and participation in internal compliance systems. In contrast, factors that may decrease the amount of a whistle-blower's award include culpability, unreasonable reporting delay, and interference with internal compliance and reporting systems. See 17 C.F.R. $\$ 240.21 \mathrm{~F}-6$ (2014); Farag and Dworkin 2016 Southern Law Journal 36. 
largest award to a whistle-blower in terms of the programme - namely, USD 30 million. $^{213}$

It should be noted that Code section 6103(a) mandates that return information is regarded as confidential and cannot be disclosed without the taxpayer's consent, absent an express statutory exception. ${ }^{214}$ Such an exception is contained in section 6103(n), which provides that returns and return information may be disclosed to any person to the extent "necessary in connection with the processing, storage, transmission, and reproduction of such returns ${ }^{215}$ and return information, ${ }^{216}$ the programming, maintenance, repair, testing, and procurement of equipment, and the providing of other services, for purposes of tax administration". Goulder points out that "tax administration contracts" include those between the IRS and informants under the whistle-blower programme and that the justification for nonconsensual disclosure is "that evidence of the taxpayer noncompliance could be difficult for the Service to identify and substantiate". ${ }^{217}$ It should also be noted that some of the factors that could be considered if a 6103(n) contract exists are the following: (i) issues involving transactions not recorded on the

213 Bloomberg "Whistle-Blower Said to Get Record 30 Million from CFTC (12 July 2018) https://www.bloomberg.com/news/articles/2018-07-12/jpmorgan-whistle-blower-said-to-getrecord-30-million-from-cftc (accessed 2018-12-30).

214 Rosenberg and Phillips "Whistleblower Claims" 5.

215 S 6103(b)(1) defines return to mean:

"any tax or information return, declaration of estimated tax, or claim for refund required by, or provided for or permitted under, the provisions of this title which is filed with the Secretary by, on behalf of, or with respect to any person, and any amendment or supplement thereto, including supporting schedules, attachments, or lists which are supplemental to, or part of, the return so filed".

216 S 6103(b)(2) defines "return information" to mean -

"(A) a taxpayer's identity, the nature, source, or amount of his income, payments, receipts, deductions, exemptions, credits, assets, liabilities, net worth, tax liability, tax withheld, deficiencies, overassessments, or tax payments, whether the taxpayer's return was, is being, or will be examined or subject to other investigation or processing, or any other data, received by, recorded by, prepared by, furnished to, or collected by the Secretary with respect to a return or with respect to the determination of the existence, or possible existence, of liability (or the amount thereof) of any person under this title for any tax, penalty, interest, fine, forfeiture, or other imposition, or offense,

(B) any part of any written determination or any background file document relating to such written determination (as such terms are defined in section 6110(b)) which is not open to public inspection under section 6110 ,

(C) any advance pricing agreement entered into by a taxpayer and the Secretary and any background information related to such agreement or any application for an advance pricing agreement, and

(D) any agreement under section 7121, and any similar agreement, and any background information related to such an agreement or request for such an agreement, but such term does not include data in a form which cannot be associated with, or otherwise identify, directly or indirectly, a particular taxpayer.

Nothing in the preceding sentence, or in any other provision of law, shall be construed to require the disclosure of standards used or to be used for the selection of returns for examination, or data used or to be used for determining such standards, if the Secretary determines that such disclosure will seriously impair assessment, collection, or enforcement under the internal revenue laws."

S 6103(b)(3) defines "taxpayer return information" to mean return information as defined in par (2) which is filed with, or furnished to, the Secretary by or on behalf of the taxpayer to whom such return information relates.

217 See, in this regard, Goulder Views from the Fourth Estate 5. 
books and records of the taxpayer; (ii) issues where the whistle-blower has substantial industry expertise (particularly when there are complex transactions, or emerging compliance issues (in which case it may be beneficial to have a whistle-blower assist in evaluating the taxpayer's responses to information document requests (IDRs); and (iii) issues involving substantial factual development where the whistle-blower's knowledge could be beneficial. ${ }^{218}$ Goulder is of the view that these factors are "a relatively 'low hurdle' to overcome".

\section{CONCLUDING REMARKS: POSSIBLE FINANCIAL OR MONETARY TAX WHISTLE-BLOWING PROGRAMME IN SOUTH AFRICA}

From the above, the benefits of having a structured whistle-blowing programme in relation to tax matters are apparent. Notably the SARS website does provide a link where suspicious activity can be reported. ${ }^{220}$ Even though there is no whistle-blowing framework specifically for tax matters, the general regulatory framework pertaining to whistle-blowers in South Africa would ensure that a whistle-blower is protected against possible reprisals. Furthermore, the relevant rights at the disposal of the "evading taxpayer" - namely, the right to access information and the right to just administrative action - would generally not include disclosing the identity of the whistle-blower.

From the discussion regarding the US's whistle-blowing incentives, it is clear that providing a financial/monetary incentive could be effective in collecting outstanding taxes. Nonetheless, according to the SARS website ${ }^{221}$ reporting a tax crime in South Africa is done without any reward. It is suggested that the possibility of providing monetary rewards should be seriously considered, as this could assist in curbing not only tax evasion, but also in creating trust between SARS and the general public in the fight against tax-related misconduct as well as improving tax collections and raising compliance rates. ${ }^{222}$

The following observations should be considered by SARS when contemplating a reward system for tax whistle-blowers: (i) confidentiality regarding the whistle-blower's information is key; (ii) the information must be previously undiscovered and be unlikely to be discovered if not for the whistle-blower; (iii) the whistle-blower must have a reasonable belief that

218 See Department of Treasury "6103(n) Contracts” (12 April 2017) https://www.irs.gov/pub/ whistleblower/wo_6103n_guidance.pdf (accessed 2018-12-30).

219 Goulder Views from the Fourth Estate 5.

220 See South Africa Revenue Service "Report a Tax or Custom Crime" (2018-11-29) https://www.sars.gov.za/TargTaxCrime/ReportCrime/Pages/default.aspx (accessed 201905-28). A whistle-blower can select whether he or she wants to remain anonymous in this respect.

221 South Africa Revenue Service "Report a Tax or Custom Crime" (2018-11-29) https://www.sars.gov.za/TargTaxCrime/ReportCrime/Pages/default.aspx (accessed 201905-28).

222 See Farag and Dworkin 2016 Southern Law Journal 20; SARS website https://bit.ly/2WMGX1t. 
the disclosure is being made in the public interest; and (iv) the whistleblower should only be eligible for a financial reward based on the amount of tax revenue eventually collected from the whistle-blowing information obtained from him or her.

It should also be noted that, although the identity of the whistle-blower should not be made known to the alleged tax evader, SARS will have to require that tax whistle-blowers not submit claims anonymously, as is the current practice, as SARS will have to assess not only the credibility of the information, but also that of the tax whistle-blower. ${ }^{223}$ Education regarding the tax whistle-blowing programme should also explicitly emphasise the antireprisal provisions that will protect the tax whistle-blower against harassment, victimisation, criminal sanctions, and so forth. It is also of utmost importance that this programme should timeously process whistleblowing claims and that there should be proper communication channels between the whistle-blower and SARS in order to facilitate the whistleblowing process as well as keep the identity of the whistle-blower and the information intact.

${ }^{223}$ See Farag and Dworkin 2016 Southern Law Journal 32. 